\title{
Quantification of the depletion of ozone in the plume of Mount Etna
}

\author{
L. Surl ${ }^{1}$, D. Donohoue ${ }^{1, *}$, A. Aiuppa ${ }^{2,3}$, N. Bobrowski ${ }^{4}$, and R. von Glasow ${ }^{1}$ \\ ${ }^{1}$ Centre for Ocean and Atmospheric Sciences, School of Environmental Sciences, University of East Anglia, \\ Norwich, NR4 7TJ, UK \\ ${ }^{2}$ DiSTeM, Università di Palermo, 90123 Palermo, Italy \\ ${ }^{3}$ Istituto Nazionale di Geofisica e Vulcanologia, Sezione di Palermo, Via La Malfa 153, 90146 Palermo, Italy \\ ${ }^{4}$ Institut für Umweltphysik, Universität Heidelberg, Im Neuenheimer Feld 229, 69120 Heidelberg, Germany \\ *now at: Department of Chemistry, Lawrence University, Appleton, Wisconsin, 54911, USA
}

Correspondence to: L. Surl (1.surl@uea.ac.uk)

Received: 26 June 2014 - Published in Atmos. Chem. Phys. Discuss.: 12 September 2014

Revised: 19 January 2015 - Accepted: 12 February 2015 - Published: 9 March 2015

\begin{abstract}
Volcanoes are an important source of inorganic halogen species into the atmosphere. Chemical processing of these species generates oxidised, highly reactive, halogen species which catalyse considerable $\mathrm{O}_{3}$ destruction within volcanic plumes. A campaign of ground-based in situ $\mathrm{O}_{3}$, $\mathrm{SO}_{2}$ and meteorology measurements was undertaken at the summit of Mount Etna volcano in July/August 2012. At the same time, spectroscopic measurements were made of $\mathrm{BrO}$ and $\mathrm{SO}_{2}$ columns in the plume downwind.

Depletions of ozone were seen at all in-plume measurement locations, with average $\mathrm{O}_{3}$ depletions ranging from 11$35 \mathrm{nmol} \mathrm{mol}^{-1}(15-45 \%)$. Atmospheric processing times of the plume were estimated to be between 1 and 4 min. A 1$\mathrm{D}$ numerical model of early plume evolution was also used. It was found that in the early plume $\mathrm{O}_{3}$ was destroyed at an approximately constant rate relative to an inert plume tracer. This is ascribed to reactive halogen chemistry, and the data suggests the majority of the reactive halogen that destroys $\mathrm{O}_{3}$ in the early plume is generated within the crater, including a substantial proportion generated in a high-temperature "effective source region" immediately after emission. The model could approximately reproduce the main measured features of the ozone chemistry. Model results show a strong dependence of the near-vent bromine chemistry on the presence or absence of volcanic $\mathrm{NO}_{\mathrm{x}}$ emissions and suggest that near-vent ozone measurements can be used as a qualitative indicator of $\mathrm{NO}_{\mathrm{x}}$ emission.
\end{abstract}

\section{Introduction}

Volcanoes are known to be a major source of climatically important species, trace gases, and aerosol into the atmosphere, both through explosive eruptions and sustained quiescent degassing (e.g. von Glasow et al., 2009). The largest gaseous components of most eruptions are water, carbon dioxide and sulphur compounds, followed by hydrogen halides (Symonds et al., 1994). These volcanogenic halides are known to present environmental hazards upon deposition to soils (e.g. Delmelle et al., 2003). Emissions of bromide, while weaker and less well studied than those of fluoride and chloride (Pyle and Mather, 2009), are of interest to atmospheric chemistry due to the conversion of $\mathrm{HBr}$ to very reactive ozone-depleting bromine species (Bobrowski et al., 2003, 2007; Bobrowski and Platt, 2007; Gerlach, 2004; von Glasow et al., 2009; von Glasow, 2010; Oppenheimer et al., 2006; Kern et al., 2009; Roberts et al., 2009, 2014; Kelly et al., 2013).

The bromine explosion is an autocatalytic chemical reaction cycle which is known to convert bromine from $\mathrm{HBr}$ to very reactive forms (Wennberg, 1999). It is considered to be the reason for detections of elevated $\mathrm{BrO}$ associated with depleted $\mathrm{O}_{3}$ (e.g. von Glasow et al., 2009; Saiz-Lopez and von Glasow, 2012). 


$$
\begin{aligned}
& \mathrm{BrO}_{(\mathrm{g})}+\mathrm{HO}_{2(\mathrm{~g})} \longrightarrow \mathrm{HOBr}_{(\mathrm{g})}+\mathrm{O}_{2(\mathrm{~g})} \\
& \mathrm{HOBr}_{(\mathrm{g})} \longrightarrow \mathrm{HOBr}_{(\mathrm{aq})} \\
& \mathrm{HBr}_{(\mathrm{g})} \longrightarrow \mathrm{HBr}_{(\mathrm{aq})} \\
& \mathrm{HOBr}_{(\mathrm{aq})}+\mathrm{Br}^{-}+\mathrm{H}^{+} \longrightarrow \mathrm{Br}_{2(\mathrm{aq})}+\mathrm{H}_{2} \mathrm{O}_{(\mathrm{l})} \\
& \mathrm{Br}_{2(\mathrm{aq})} \longrightarrow \mathrm{Br}_{2(\mathrm{~g})} \\
& \mathrm{Br}_{2(\mathrm{~g})}+h v \longrightarrow 2 \mathrm{Br}_{(\mathrm{g})} \\
& 2\left(\mathrm{Br}_{(\mathrm{g})}+\mathrm{O}_{3(\mathrm{~g})}\right) \longrightarrow 2\left(\mathrm{BrO}_{(\mathrm{g})}+\mathrm{O}_{2(\mathrm{~g})}\right)
\end{aligned}
$$

There is no equivalent chlorine explosion as $\mathrm{HCl}$ is less reactive than $\mathrm{HBr}$ (see von Glasow et al., 2009).

In the troposphere, reactive halogen species catalyse ozone destructive cycles (e.g. Saiz-Lopez and von Glasow, 2012) ( $\mathrm{X}$ and $\mathrm{Y}$ are halogen atoms):

$$
\begin{aligned}
& \mathrm{XO}_{(\mathrm{g})}+\mathrm{YO}_{(\mathrm{g})} \longrightarrow \mathrm{X}_{(\mathrm{g})}+\mathrm{Y}_{(\mathrm{g})}+\mathrm{O}_{2(\mathrm{~g})} \\
& \mathrm{XO}_{(\mathrm{g})}+\mathrm{YO}_{(\mathrm{g})} \longrightarrow \mathrm{XY}_{(\mathrm{g})}+\mathrm{O}_{2(\mathrm{~g})} \\
& \mathrm{XY}_{(\mathrm{g})}+h \mathrm{v} \longrightarrow \mathrm{X}_{(\mathrm{g})}+\mathrm{Y}_{(\mathrm{g})} \\
& \mathrm{X}_{(\mathrm{g})}+\mathrm{O}_{3(\mathrm{~g})} \longrightarrow \mathrm{XO}_{(\mathrm{g})}+\mathrm{O}_{2(\mathrm{~g})} \\
& \mathrm{Y}_{(\mathrm{g})}+\mathrm{O}_{3(\mathrm{~g})} \longrightarrow \mathrm{YO}_{(\mathrm{g})}+\mathrm{O}_{2(\mathrm{~g})} .
\end{aligned}
$$

Reactive halogen chemistry and related $\mathrm{O}_{3}$ depletion has been studied in detail in the polar and marine boundary layers and over salt lakes (see Saiz-Lopez and von Glasow, 2012, for an overview).

$\mathrm{BrO}$ is detectable through spectroscopy, and detection of elevated levels are used as an indicator for the occurrence of reactive bromine chemistry. $\mathrm{BrO}$ was first detected in a volcanic plume by Bobrowski et al. (2003), and has, to date, been detected in the plumes of about 20 different volcanoes. A good overview of ground-based measurements of $\mathrm{BrO}$ in volcanic plumes can be found in Boichu et al. (2011) and references therein. A systematic study of satellite data by Hörmann et al. (2012) greatly extended the data set of known $\mathrm{BrO}$ events detected via satellite measurements.

In both satellite and ground-based studies, in-plume ratios of $\mathrm{BrO}$ to $\mathrm{SO}_{2}$ have been found to be of the order of $10^{-5}$ several $10^{-4}$ once the plume has been transported a few $\mathrm{km}$ from the source (e.g. Bobrowski et al., 2007; Boichu et al., 2011; Hörmann et al., 2012). Measurements and modelling studies of in-plume $\mathrm{BrO} / \mathrm{SO}_{2}$ ratios have shown $\mathrm{BrO}$ to be either present at low levels or undetectable within $1 \mathrm{~km}$ of volcanic vents whilst the $\mathrm{BrO} / \mathrm{SO}_{2}$ ratio a few km down-

\begin{tabular}{|c|c|c|}
\hline Volcano & $\begin{array}{l}\text { Measurement } \\
\text { platform }\end{array}$ & Reference \\
\hline Augustine & airborne & Vance et al. (2010) \\
\hline Erebus & airborne & $\begin{array}{l}\text { Oppenheimer et al. (2010) } \\
\text { Boichu et al. (2011) }\end{array}$ \\
\hline Etna & ground-based & Vance et al. (2010) \\
\hline Eyjafjallajökull & airborne & $\begin{array}{l}\text { Vance et al. (2010) } \\
\text { Schumann et al. (2011) }\end{array}$ \\
\hline St. Helens & airborne & Hobbs et al. (1982) \\
\hline Redoubt & airborne & Kelly et al. (2013) \\
\hline Sakurajima & ground-based & Lee et al. (2005) \\
\hline
\end{tabular}
wind of the same vent is measured as up to several $10^{-4}$ (e.g. Bobrowski et al., 2007; Kern et al., 2009). This suggests the formation of $\mathrm{BrO}$ is occurring within the time taken for this downwind transport. $\mathrm{SO}_{2}$ is widely used as a tracer for volcanic emissions due to its high concentration in volcanic plumes, low reactivity, and easily detectable spectroscopic signal (McGonigle et al., 2004).

Volcanoes are known to emit other halogens $(\mathrm{F}, \mathrm{Cl}, \mathrm{I})$. The HF molecule is expected to be too stable for any in-plume
Table 1. Table of reported depletions of $\mathrm{O}_{3}$ in tropospheric volcanic plumes.

reactive $\mathrm{F}$ chemistry to occur (von Glasow et al., 2009), whilst the magnitudes of volcanic HI emissions are probably too low to have a significant effect on plume chemistry (Aiuppa et al., 2005a). Measurements of oxidised $\mathrm{Cl}$ in volcanic plumes are varied, having been observed at Sakurajima (Lee et al., 2005), Etna (Bobrowski et al., 2007; General et al., 2014), Puyehue-Cordón Caulle (Theys et al., 2014), and Soufière Hills (Donovan et al., 2014). However a DOAS investigation by Kern et al. (2009) specifically looking for oxidised $\mathrm{Cl}$ did not detect any in the plume of Masaya Volcano. It is unknown whether this reflects natural variability or measurement issues. See Roberts et al. (2009) for a discussion of reactive chlorine formation in volcanic plumes.

The conceptual model of halogen- $\mathrm{O}_{3}$ chemistry within volcanic plumes is complicated by the very high temperatures of the plume immediately after emission and mixing with the atmosphere. Such high temperature mixtures are believed to reach or approach thermodynamic equilibrium (Symonds et al., 1994), resulting in the production of non-negligible quantities of oxidised halogen species which may begin the autocatalytic cycles described above (Gerlach, 2004; Bobrowski et al., 2007; Martin et al., 2009). Because of the hazards involved, this "effective source region" within the crater (Bobrowski et al., 2007) cannot be investigated directly. Instead, inventories of volcanic emission species are based mostly on samples of fumarole emissions or craterrim measurements (Gerlach, 2004). Processes occurring in the effective source region are inferred from these measurements, theory, and measurements of the plume further downwind.

While $\mathrm{BrO}$ (and, with greater difficulty, OClO) can be measured remotely using passive spectroscopic techniques, direct measurements of $\mathrm{O}_{3}$ depletion within volcanic plumes have to be made in situ due to the large atmospheric $\mathrm{O}_{3}$ column, and as a result the existing body of literature on the depletion of ozone within volcanic plumes is small, see Table 1. Active DOAS measurement of $\mathrm{O}_{3}$ at a volcano is possible, however it presents significant difficulties in distinguishing the plume from background air. To the authors' knowledge 


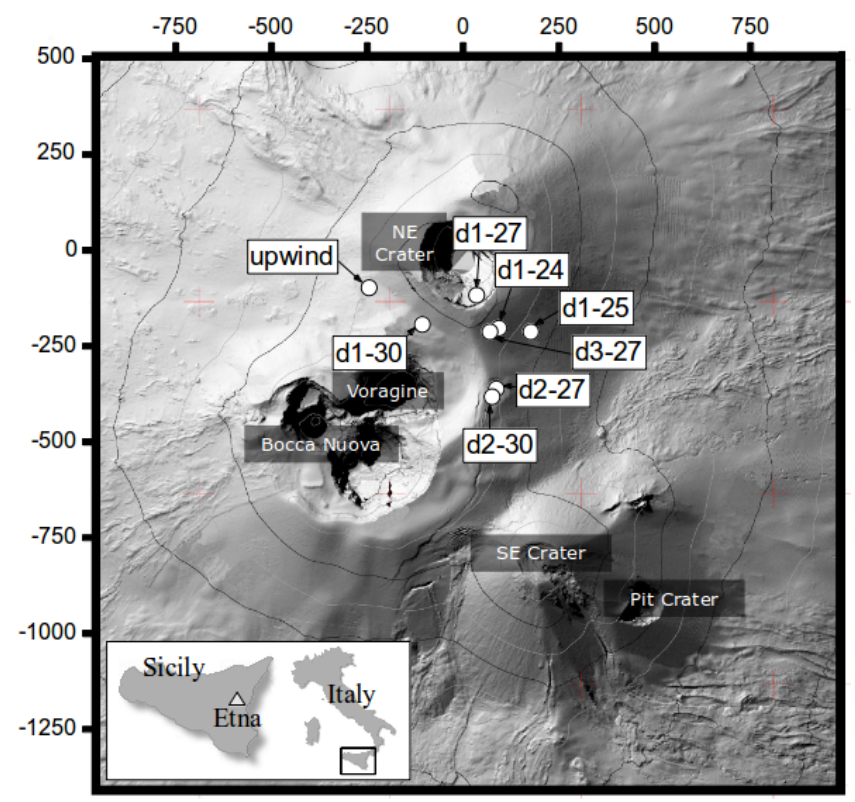

Figure 1. Map of the sampling sites and summit craters. Terrain from Neri et al. (2009). Coordinates are metres displacement from the NE crater.

the only published active DOAS $\mathrm{O}_{3}$ measurement at a volcano is Kern et al. (2009). In this investigation, no $\mathrm{O}_{3}$ depletion could be determined - the authors of this publication attribute this to the difficulties of isolating a plume $\mathrm{O}_{3}$ signal from that of the background air.

This study expands this small collection of $\mathrm{O}_{3}$ observations. In addition, the $\mathrm{O}_{3}$ depletion data collected are associated with simultaneous measurements of an inert plume tracer $\left(\mathrm{SO}_{2}\right)$. To the authors' knowledge, no prior data set exists of simultaneous measurements of $\mathrm{O}_{3}$ depletion and a tracer species within $1 \mathrm{~km}$ of volcanic vents. Wind speeds have also been measured, such that processing time can be determined for every datapoint. As in-plume halogen and $\mathrm{O}_{3}$ chemistry are closely linked, from these data we can investigate both qualitatively and quantitatively the fast chemical processes occurring within the early plume.

\section{Campaign and data processing}

\subsection{Location}

The measurement campaign was conducted at Mount Etna, Sicily, Italy $\left(37.7^{\circ} \mathrm{N}, 15.0^{\circ} \mathrm{E}\right)$ with the majority of measurements being taken between 24 July and 2 August 2012. Mount Etna is an active stratovolcano with a peak elevation of about $3300 \mathrm{~m}$. At the time of measurement, the volcano was in a passively degassing phase with three active vents (North-East, Voragine and Bocca Nuova) within our survey area. Small Strombolian eruptions and an inner-crateric lava flow were observed at Bocca Nuova but explosive ejecta only rarely surpassed the crater rim. Due to the vicinity of the Voragine and Bocca Nuova craters it was not possible to distinguish between their plumes. Therefore in this analysis we have considered them to be a single source, which we define as the "central craters".

Most of the measurements were taken near the crater rim at elevations significantly above the planetary boundary layer. Due to logistical constraints we took these measurements between 08:40 and 12:00 UTC (10:40-14:00 local time). The sky was cloud-free on all days of measurement. The groundbased remote sensing measurements of the plume were taken from locations further downwind with plume ages of up to $30 \mathrm{~min}$.

On all days of near-crater measurements we took measurements at a fixed site that was upwind of all summit craters and at 1-3 sites in the plume at varying distances from the craters (Fig. 1). This was done to sample plumes at different processing times. Sampling times at the sites varied between 20 and $60 \mathrm{~min}$ (see Table 3 ).

The names given to the near-crater measurement sites in the figures and in Table 3 indicate the day on which the measurements were taken and the order in which they were measured. For example, site "d2-27" was the second downwind site measured on 27 July. All upwind measurements were taken at the same location. In Table 3, the upwind site data sets collected on each day have been treated separately. For example, "up-30" is the set of measurements taken at the upwind site on 30 July.

\subsection{Instrumentation}

Ozone mixing ratios were measured via UV adsorption with a 2B Technologies instrument, model 202. A particle filter was placed on the inlet to prevent aerosols from influencing data or damaging the instrument. Because of the overlap of the $\mathrm{O}_{3}$ and $\mathrm{SO}_{2}$ adsorption spectra (e.g. Vance et al., 2010) we also fitted the inlet with two $\mathrm{SO}_{2}$ scrubbers in series to prevent interference in the $\mathrm{O}_{3}$ measurements. The scrubbers were packed with $\mathrm{CrO}_{3}$-coated microfibre filter paper. We tested the endurance of the scrubbers prior to the campaign. Air with a $\mathrm{SO}_{2}$ mixing ratio of $700 \mu \mathrm{mol} \mathrm{mol}^{-1}$ was passed through the setup at a flow rate of $0.58 \mathrm{~L} \mathrm{~min}^{-1}$. No $\mathrm{SO}_{2}$ related signal could be detected on the $\mathrm{O}_{3}$ monitor for $2.25 \mathrm{~h}$, a removal of approximately $15 \mathrm{mg}$ of $\mathrm{SO}_{2}$. This greatly exceeds the expected $\mathrm{SO}_{2}$ exposure of the scrubbers in the field.

New scrubbers and particulate filters were used daily. We calibrated the ozone monitor and inlet setup daily with a 2B Technologies model $306 \mathrm{O}_{3}$ calibration source. Linear losses of $\mathrm{O}_{3}$ in the inlet/scrubber system was detected, the field results each day were corrected using the results from the calibration. We determined a measurement error of $\pm 3 \mathrm{nmol} \mathrm{mol}^{-1}$ from the calibration results, which incorporates both random error of the instrument and uncertainties in the calibration correction. 
We measured several gases' mixing ratios with a portable version of the INGV-type multi-component gas analyser system (MULTIGAS) (Aiuppa et al., 2011, 2012), though only the $\mathrm{SO}_{2}$ measurements have been used in this analysis. The $\mathrm{SO}_{2}$ measurement used an electrochemical sensor $\left(0-200 \mu \mathrm{mol} \mathrm{mol}^{-1} ; 3 \mathrm{ST} / \mathrm{F}\right.$ electrochemical sensor, City Technology Ltd.). A protective particulate filter was included on the instrument inlet. Data were recorded on an on-board data-logger and stored internally. The instrument's sensors and data-logger were housed in a water-proof box with a $1.2 \mathrm{~L} \mathrm{~min}^{-1}$ pump and a $12 \mathrm{~V}$ battery. The sensors were calibrated before and after fieldwork with standard calibration gases; the instrument's accuracy and precision were determined to both be about $20 \%$. The MULTIGAS was not used for the first 2 days of the campaign ( 24 and 25 July).

Temperature, humidity and wind vector were measured with a Kestrel 4500 commercial weather station, mounted on a tripod. Prior to the campaign, the device's relative humidity measurement was calibrated with standardised salt solutions.

Each instrument recorded data at a different frequency. Table 2 shows the instruments' measurement intervals and precision errors.

At the measurement sites we set up the ozone monitor and MULTIGAS on the same tripod, with the inlet tubes positioned closely together. The weather station tripod was positioned within $5 \mathrm{~m}$ of the tripod supporting the in situ instruments. The locations of the sites were determined by handheld GPS. The source of the plume at each downwind site was determined visually.

Remote sensing measurements of the downwind evolution of the volcanic plume with two Mini-MAXDOAS (multiaxis differential optical absorption spectroscopy) instruments were carried out (see Bobrowski et al., 2007, for an instrument description). Scans approximately perpendicular to the plume axis were made at distances between 6 and $16.6 \mathrm{~km}$ from the craters, corresponding to plume ages between about 8 and $30 \mathrm{~min}$.

\subsection{Data processing}

The instruments listed in Table 2 each had independent internal clocks which could only be roughly synchronised in the field. The MULTIGAS' internal clock does not record absolute time, but only time since the device was switched on. In the field, we turned the device on at the same time as the other instruments, however it is probable some de-synchronisation of the data sets has occurred because of this. Inspection of the $\mathrm{O}_{3}$ and $\mathrm{SO}_{2}$ signal suggests that this de-synchronisation may have been up to $25 \mathrm{~s}$.

We used the upwind site data sets as reference values of the background air. For each downwind site, the $\mathrm{O}_{3}$ concentration time-series was converted to a time-series of $\mathrm{O}_{3}$ change $\left(\Delta \mathrm{O}_{3}\right)$ using the average $\mathrm{O}_{3}$ mixing ratio measured at the upwind reference site on that day.

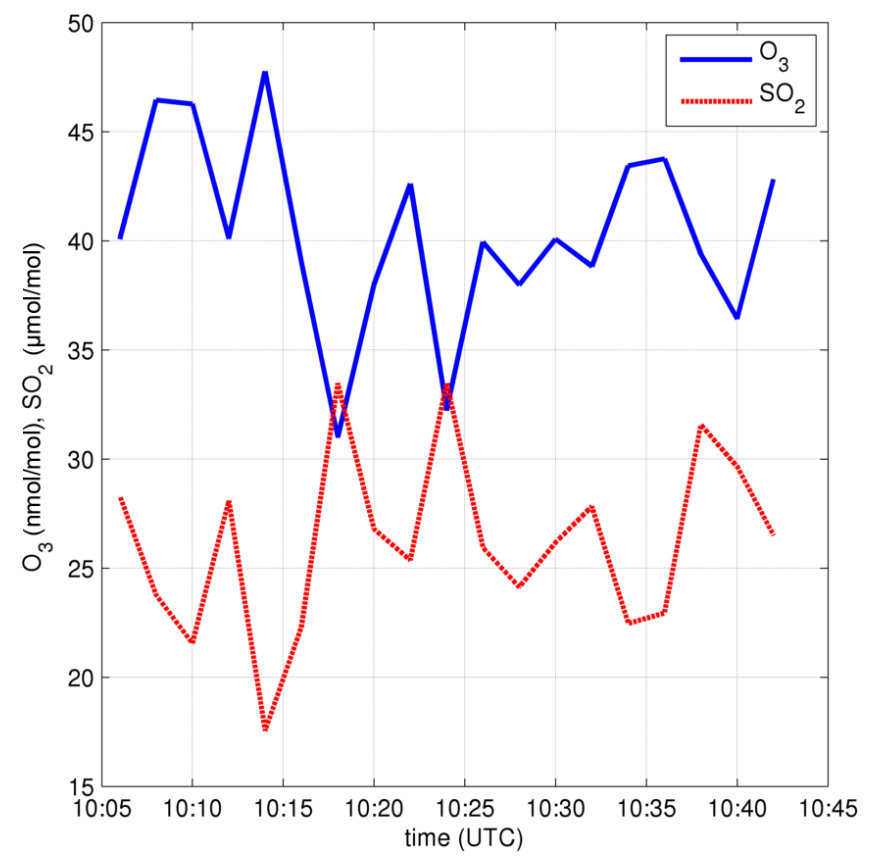

Figure 2. An example time series of measurements: $\mathrm{O}_{3}$ and $\mathrm{SO}_{2}$ mixing ratios measured in the plume at site d1-27. Data have been averaged into $120 \mathrm{~s}$ bins as described in the text.

As the collection frequency of the instruments differed, the data were binned into $120 \mathrm{~s}$ bins. Each $120 \mathrm{~s}$ bin therefore covered several measurements from each instrument and for each parameter a mean value was calculated. The use of $120 \mathrm{~s}$ bins reduced the precision error on the resulting data points. Additionally, the use of $120 \mathrm{~s}$ bins is expected to reduce the impact of any potential asynchronisation resulting from either the problem discussed above or from different instrument response times.

Inspection of the signals (e.g. Fig. 2) showed clear anticorrelation between the $\mathrm{O}_{3}$ and $\mathrm{SO}_{2}$ mixing ratios.

$\mathrm{SO}_{2}$ is used as the inert plume tracer, a measure of plume strength for the bin. Measured background levels of $\mathrm{SO}_{2}$ were negligible in comparison to in-plume measurements, and $\mathrm{SO}_{2}$ is expected to be effectively chemically inert. For each 120 s measurement bin a ratio $\Delta \mathrm{O}_{3} / \mathrm{SO}_{2}$ (change in molecules $\mathrm{O}_{3}$ per molecule inert plume tracer) was calculated, this is a measure of $\mathrm{O}_{3}$ change that is attributable to chemical and not physical processes (a proof of this can be found in the appendix).

Transport times between the craters and the downwind sites were determined from the distances between the sites and the vents, and the measured wind speeds.

For each bin, the uncertainty in the wind speed is calculated by adding in quadrature the expected error of the Kestrel instrument and the variance of the individual windspeed measurements which are averaged to yield the wind speed value for the bin. This error can be seen in the $x$ axis error bars on Figs. 3, 4, and 5. Similarly the uncertainty in 
Table 2. Instruments used at the near crater sites.

\begin{tabular}{llll}
\hline Name & Parameter & Precision & Sampling interval \\
\hline & Temperature & $\pm 1{ }^{\circ} \mathrm{C}$ & \\
Kestel 4500 & Humidity & $\pm 3 \% \mathrm{RH}$ & $30 \mathrm{~s}$ \\
& Wind speed & $\pm 3 \%$ or $\pm 1 \mathrm{~m} \mathrm{~s}^{-1}$ (whichever larger) & \\
MULTIGAS & $\mathrm{SO}_{2}$ & $\pm 20 \%$ & $2 \mathrm{~s}$ \\
2B Technologies Model 202 & $\mathrm{O}_{3}$ & $\pm 3 \mathrm{nmol} \mathrm{mol}^{-1}$ & $10 \mathrm{~s}$ \\
\hline
\end{tabular}

the $\mathrm{SO}_{2}$ values is calculated from the variance of this quantity within the bin and the instrument error. The uncertainty in the $\mathrm{O}_{3}$ values is calculated in the same manner, and for $\Delta \mathrm{O}_{3}$ measurement additionally factor in the variance in the $\mathrm{O}_{3}$ measurement in the corresponding background measurement. These errors are manifest in the $y$ axis error bars of Figs. 3 and 4, and are combined to give the $y$ axis error bars of Fig. 5.

Gaseous elemental mercury is known to be emitted by Etna (Bagnato et al., 2007) and has the potential to cause interference with UV-based ozone monitors (EPA, 1999), giving false $\mathrm{O}_{3}$ signal when in the sampled air. The inlet and $\mathrm{CrO}_{3}$ scrubbers were not tested against mercury interference. If elemental mercury was entering the monitor in the mixing ratios observed by Bagnato et al. (2007), and causing interference of the magnitudes seen by EPA (1999), it would have caused us to make underestimations of the depletion of $\mathrm{O}_{3}$ on the order of $10 \mathrm{nmol} \mathrm{mol}^{-1}$. However, this would assume that all the mercury emitted from the volcano was primarily in the elemental form. This is unlikely as modelling studies (von Glasow, 2010) indicated that much on the mercury is oxidised within the plume. In addition, mercury measurements at Etna contemporaneous with our campaign (T. A. Mather and M. L. Witt, personal communication, 2014) indicate that the mercury loading of the craters' plumes were significantly less than that which was measured by Bagnato et al. (2007) in 2004-2007 and confirmed that much of the observed mercury was in an oxidised or particulate form. It is also probable that the two $\mathrm{CrO}_{3}$ scrubbers scavenged or oxidised much of the elemental mercury in the sampled air, as the system is not heated and the scrubbers are changed daily it is unlikely that mercury scavenged by the scrubber would be re-volatilised as elemental mercury. No compensation for this potential effect was made in the post-processing as we believe that the potential for this interference is very low and because the observed anti-correlation of the $\mathrm{O}_{3}$ and $\mathrm{SO}_{2}$ signals is the inverse of what would be expected from such interference.

The MAXDOAS data were evaluated for $\mathrm{BrO}$ and $\mathrm{SO}_{2}$ with the WinDOAS V2.10 software package (van Roozendael and Fayt, 2001) which uses a nonlinear least-square method (Stutz and Platt, 1996). A BrO $/ \mathrm{SO}_{2}$ ratio was calculated for each measurement day by a correlation plot of the daily data set. The plume ages at the point of measurement were calculated from the wind speed and lateral distance

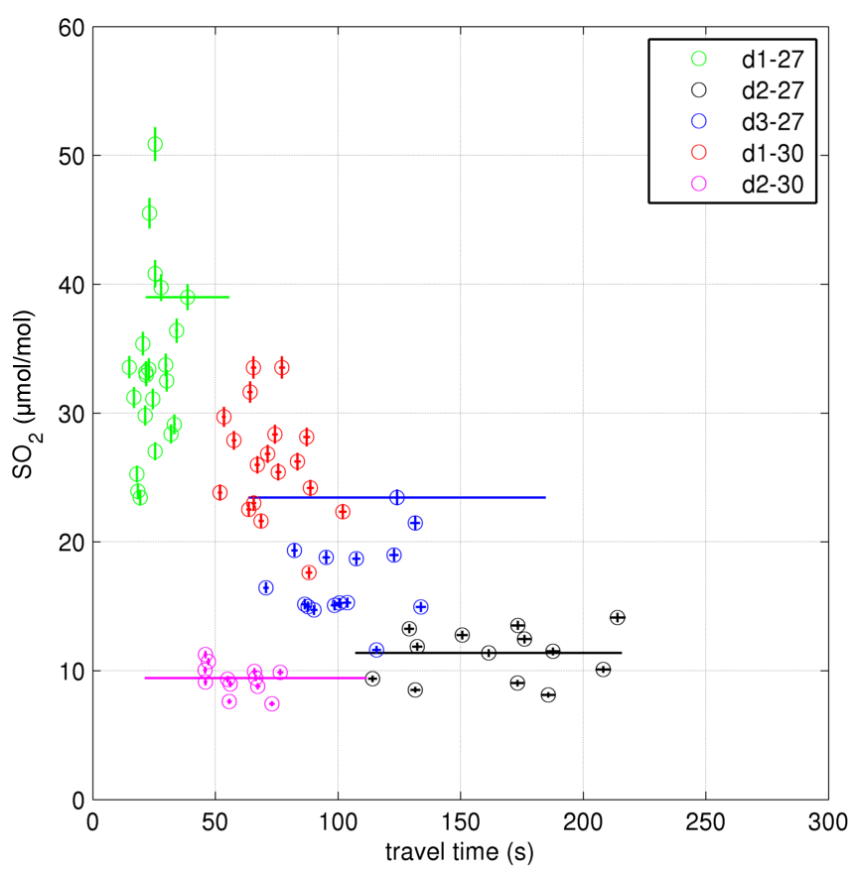

Figure 3. $\mathrm{SO}_{2}$ mixing ratios against calculated processing time at the in-plume measurement sites. Error bars are 1 standard deviation, accounting for both variance in the values over the $120 \mathrm{~s}$ of each bin and known errors of the instruments.

from the craters. In the absence of wind speed data at Etna, speeds from soundings taken at Trapani $\left(37.91^{\circ} \mathrm{N}, 12.50^{\circ} \mathrm{E}\right.$, data from http://weather.uwyo.edu/upperair/sounding.html) were used. The $220 \mathrm{~km}$ distance between the location of the soundings and the volcano means that there is a relatively large and unquantifiable uncertainty in the calculated plume ages.

\section{Results}

An overview of the near-crater results from this campaign can be seen in Table 3. Calculated plume ages were found to be of the order 1-4 min.

The plume was observed to be grounded at all downwind sites, enabling measurement. As both $\mathrm{O}_{3}$ and $\mathrm{SO}_{2}$ are known to exhibit deposition to the ground, there is the potential for the mixing ratios of these species at the elevation of the in- 
Table 3. Overview of results from Etna summit measurement campaign.

\begin{tabular}{|c|c|c|c|c|c|c|c|c|c|c|c|}
\hline \multirow[t]{2}{*}{ Site } & \multirow{2}{*}{$\begin{array}{l}\text { Upwind/ } \\
\text { Downwind }\end{array}$} & \multirow{2}{*}{$\begin{array}{l}\text { Plume } \\
\text { Source }\end{array}$} & \multirow{2}{*}{$\begin{array}{r}\text { Distance to } \\
\text { source/m }\end{array}$} & \multirow[t]{2}{*}{ Date } & \multirow{2}{*}{ Time (UTC) } & & \multicolumn{4}{|c|}{ Average Values } & \multirow[b]{2}{*}{$\begin{array}{r}\Delta\left[\mathrm{O}_{3}\right] / \\
\mathrm{nmol} \mathrm{mol}^{-1}\end{array}$} \\
\hline & & & & & & & $\begin{array}{r}\text { Temp./ } \\
{ }^{\circ} \mathrm{C}\end{array}$ & $\begin{array}{r}\text { Humidity/ } \\
\%\end{array}$ & $\begin{array}{r}{\left[\mathrm{SO}_{2}\right] /} \\
\mu \mathrm{mol} \mathrm{mol} \\
\mathrm{mol}^{-1}\end{array}$ & $\begin{array}{r}{\left[\mathrm{O}_{3}\right] /} \\
\mathrm{nmol} \mathrm{mol} \\
-1\end{array}$ & \\
\hline up-24 & Upwind & - & - & $2012-07-24$ & 09:10-09:35 & 3 & 49 & 3 & n.m. & 86 & - \\
\hline d1-24 & Downwind & Central & 300 & $2012-07-24$ & 10:05-11:30 & 7 & 64 & 7 & n.m. & 69 & -18 \\
\hline up- 25 & Upwind & - & - & $2012-07-25$ & 11:05-11:30 & 7 & 63 & 7 & n.m. & 83 & - \\
\hline d $1-25$ & Downwind & Central & 440 & $2012-07-25$ & 09:52-10:30 & 11 & 60 & 11 & n.m. & 58 & -25 \\
\hline up-27 & Upwind & - & - & $2012-07-27$ & 08:41-09:02 & 9 & 59 & 9 & 0 & 77 & - \\
\hline d $1-27$ & Downwind & NEC & 150 & $2012-07-27$ & 09:26-10:16 & 11 & 49 & 11 & 34 & 46 & -31 \\
\hline $\mathrm{d} 2-27$ & Downwind & NEC & 380 & $2012-07-27$ & 10:34-11:06 & 13 & 42 & 13 & 11 & 50 & -26 \\
\hline d3-27 & Downwind & NEC & 240 & $2012-07-27$ & $11: 20-11: 50$ & 13 & 34 & 13 & 17 & 41 & -35 \\
\hline up-30 & Upwind & - & - & 2012-07-30 & 09:12-09:34 & 12 & $<5$ & 12 & 0 & 73 & - \\
\hline d $1-30$ & Downwind & Central & 240 & 2012-07-30 & 10:05-10:43 & 16 & 6 & 16 & 26 & 40 & -32 \\
\hline $\mathrm{d} 2-30$ & Downwind & Central & 300 & $2012-07-30$ & $11: 07-11: 41$ & 15 & 5 & 15 & 9 & 62 & -11 \\
\hline
\end{tabular}

n.m.: $\mathrm{SO}_{2}$ was not measured on these days.

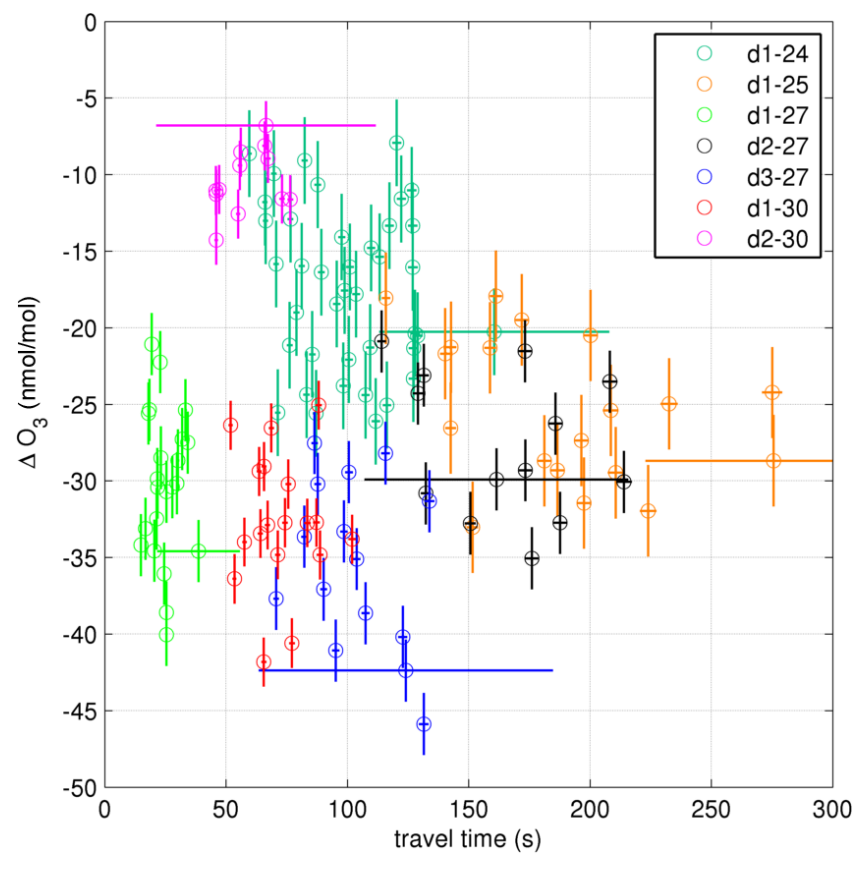

Figure 4. $\Delta \mathrm{O}_{3}$ against calculated processing time at the in-plume measurement sites. Error bars are 1 standard deviation, accounting for both variance in the values over the $120 \mathrm{~s}$ of each bin and known errors of the instruments.

struments to be perturbed by this physical process. However the ground at the peak of Etna is rocky and devoid of vegetation and could be classed in the scheme of Wesely (1989) as "barren land". The bulk surface resistance of this category sufficiently high that, even if the aerodynamic and sublayer resistances are low, the deposition velocity will be too low to cause a significant perturbation during the transport from crater rim to the measurement sites.

Ozone depletion of up to $45 \%$ was observed at all seven downwind sites. $\mathrm{SO}_{2}$ decreases with transport time (Fig. 3), as would be expected due to dilution. The low $\mathrm{SO}_{2}$ mixing

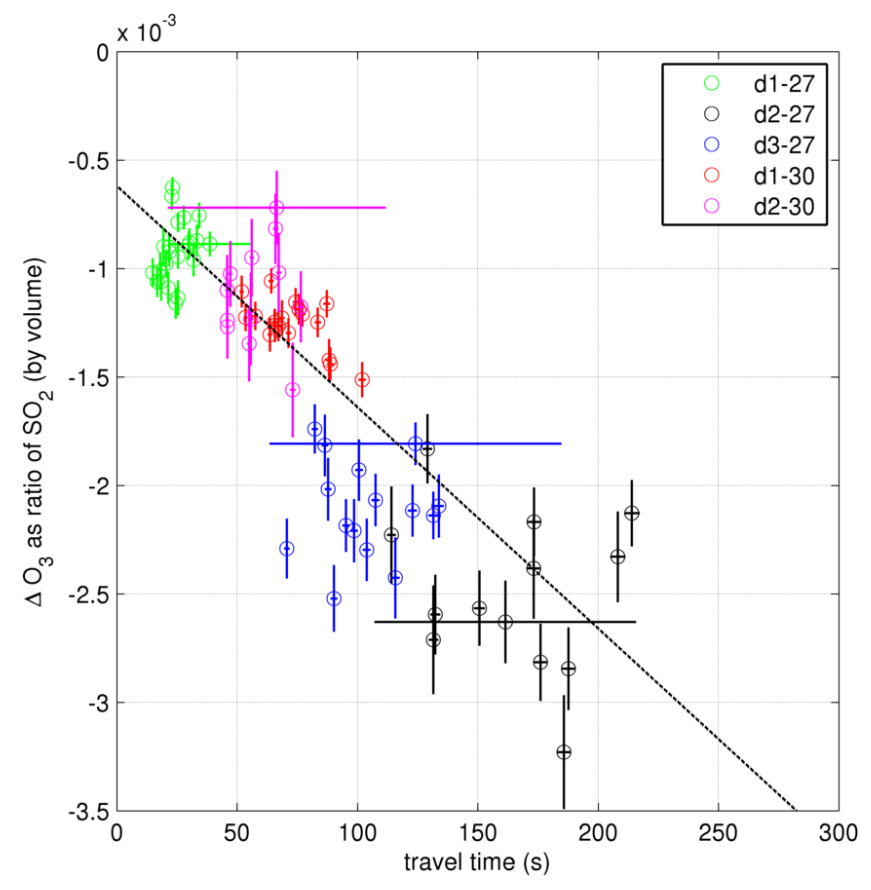

Figure 5. $\Delta \mathrm{O}_{3} / \mathrm{SO}_{2}$ against calculated processing time at the inplume measurement sites. The gradient of the linear line of best fit is $-(1.02 \pm 0.07) \times 10^{-5} \mathrm{~s}^{-1}$ and the $y$-intercept is $(-6.2 \pm 0.5) \times$ $10^{-4}$. Error bars are 1 standard deviation, accounting for both variance in the values over the $120 \mathrm{~s}$ of each bin and known errors of the instruments.

ratios at site $\mathrm{d} 2-30$ suggest this site was at the plume edge, this is consistent with visual observations of the plume. A plot of $\Delta \mathrm{O}_{3}$ against transport time (Fig. 4) shows no comparable trend as chemical destruction of $\mathrm{O}_{3}$ and dilution with background air occur simultaneously.

In Fig. 5, $\Delta\left[\mathrm{O}_{3}\right] /\left[\mathrm{SO}_{2}\right]$ vs. transport time is plotted. The linear trend is indicative of chemical destruction of $\mathrm{O}_{3}$ occurring within the first few minutes of plume transport (see Appendix). 
The data on Fig. 5 appear to fit a linear trend. This indicates, that as a ratio to the inert plume tracer, the rate of chemical $\mathrm{O}_{3}$ destruction is constant within the first few minutes of plume evolution. In the expected chemical cycles Eq. (2), the rate of $\mathrm{O}_{3}$ destruction is dependant on the concentration of halogens in highly reactive (non-hydrogen halide) forms. Therefore a constant rate of reaction indicates that the ratio of these species to $\mathrm{SO}_{2}$ is approximately constant during the first few minutes of plume evolution.

Depletion of ozone occurred on 30 July even when the relative humidity was $<10 \%$. This is below the crystallisation point of any major aerosol component that would be expected to be present in the plume. It would therefore be expected that at such low humidities aqueous phase reactions (such as reaction 1d) would occur at a much slower rate, preventing the bromine explosion from converting $\mathrm{HBr}$ to very reactive forms of bromine. On inspection of the humidity measurements (Table 3), no significant increase in humidity due to volcanic $\mathrm{H}_{2} \mathrm{O}$ was observed at the downwind sites (the humidity variation between up-24 and d1-24 could be volcanic in origin, however it is also in the range of normal meteorological variability). The possible impacts of a short-lived elevated humidity within the crater due to volcanogenic $\mathrm{H}_{2} \mathrm{O}$ are considered with the "dry" model runs in Section 4 of this paper.

Data points from all measurement sites appear to approximately fit the same line-of-best fit on Fig. 5. This is despite the measurements spanning 2 separate days and these 2 days having very different circumstances. On 27 July the measurements were made in the plume of the North-East crater, and on 30 July the measurements were made in the plume of the central craters. The different craters are known to exhibit differing emission compositions (Aiuppa et al., 2005a). In addition, the relatively humidity on these 2 days was markedly different. It is unknown whether the cause of these two data sets' approximate alignment in Fig. 5 is due to mechanistic reasons relating to the "effective source region" (see below) or coincidence.

A linear line of best fit was calculated using a WilliamsonYork iterative bivariate analysis (Cantrell, 2008), its gradient is $(-1.02 \pm 0.07) \times 10^{-4} \mathrm{~s}^{-1}$. The $r^{2}$ value of this fit is 0.76 . This linear trend can be interpreted as there being a rate of destruction of $\mathrm{O}_{3}$ within the plume of approximately $10^{-4}$ molecules per molecule of $\mathrm{SO}_{2}$ (the inert plume tracer) per second in the first few minutes of plume evolution. $\mathrm{SO}_{2}$ is only used as a measure of plume intensity, $\mathrm{SO}_{2}$ does not play a role in $\mathrm{O}_{3}$ destruction.

Extrapolating the line of best fit on Fig. 5 results in an intercept of the $x$ axis of approximately $-60 \mathrm{~s}$. Assuming chemical $\mathrm{O}_{3}$ destruction is not instantaneous in the plume, it would be expected that the line of best fit would pass through the origin. We determine that this offset is most likely the result of inaccuracy in the calculation of processing time. Firstly, the calculation assumes that air travels in a straight line between vent and sampling point; however, the path length is likely to be greater than this due to turbulence, the topology of the mountaintop, and variation in wind direction. Second, the distances between vents and sampling points were calculated only from their lateral displacement and did not consider the time taken for vertical transport from the vent to the crater rim. From our visual observations of the plume, we estimate this vertical transport time is likely to have been of the order of a minute.

Table 4 lists the composition of volcanic volatiles. These figures are calculated from June 2012 values of $\mathrm{SO}_{2}$, $\mathrm{HF}, \mathrm{HCl}$, and $\mathrm{HBr}$ measured using various alkaline traps (Wittmer et al., 2014) (Bocca Nuova crater), as well as the MULTIGAS measurements of $\mathrm{CO}_{2}$ and $\mathrm{SO}_{2}$ made on the main campaign (using all available data). As complete characterisation of the volcanic volatiles could not be made from the June 2012 measurements alone, the ratio of the gases to $\mathrm{CO}_{2}$ were used in these calculations with absolute values of $\mathrm{H}_{2} \mathrm{O}$ and $\mathrm{CO}_{2}$ calculated from the values reported in (Aiuppa et al., 2005b). Additionally, $\mathrm{H}_{2} / \mathrm{SO}_{2}$ was taken from (Aiuppa et al., 2011), and $\mathrm{H}_{2} \mathrm{~S} / \mathrm{SO}_{2}$ was calculated from the values reported in (Aiuppa et al., 2005b). These values were then normalised to ensure that the sum equals unity.

The remote sensing results are shown in Table 5, along with the correlation between the $\mathrm{BrO}$ and $\mathrm{SO}_{2}$ columns and the estimated plume age (based upon distance from the crater and wind speed, see Sect. 2.3). The $\mathrm{BrO} / \mathrm{SO}_{2}$ column ratios are within the range typically measured both in the Etna plume (Bobrowski and Giuffrida, 2012) and volcanic plumes in general (Boichu et al., 2011; Hörmann et al., 2012), though they are at the lower end of these ranges.

\section{Modelling study}

We used a vertically resolved 1-D numerical model MISTRA to simulate the chemical evolution of the volcanic plume in the atmosphere and to test the model's performance against the data presented above. The model is the same as used in von Glasow (2010) with minor modifications. Based on previous work (Gerlach, 2004; Martin et al., 2006; von Glasow, 2010) we used the thermodynamic equilibrium model HSC (Roine, 2007) to calculate the composition of the mixture of volcanic volatiles and ambient air in the "effective source region" which is located in the crater where temperatures are high enough so that the assumption of immediate thermodynamic equilibrium is still largely valid but also enough ambient air has been entrained to oxidise the main volcanic reduced gases (mainly $\mathrm{H}_{2} \mathrm{~S}$ and $\mathrm{H}_{2}$ ) which leads to a dramatic change in halogen speciation. Recent studies (e.g. Aiuppa et al., 2007; Martin et al., 2012) have shown that the assumption of thermodynamic equilibrium is incorrect for a number of compounds, especially for $\mathrm{H}_{2} \mathrm{~S}$ and $\mathrm{NO}_{\mathrm{x}}$ which makes the use of an equilibrium model such as HSC problematic but it is still regarded to provide a better approximation of the composition of volcanic volatiles than not assuming any equili- 
Table 4. Fractional composition (by volume) of pure volcanic volatiles of Mt. Etna in June 2012 ("low Br/S") and in 2005 ("high $\mathrm{Br} / \mathrm{S}$ "). These compositions were used to initialise the HSC calculations (for results see Table S1). "High $\mathrm{Br} / \mathrm{S}$ " refers to the plume composition used in von Glasow (2010).

\begin{tabular}{lrr}
\hline Species & low Br / S & high Br / S \\
\hline $\mathrm{H}_{2} \mathrm{O}$ & $8.75 \times 10^{-1}$ & $8.57 \times 10^{-1}$ \\
$\mathrm{CO}_{2}$ & $9.76 \times 10^{-2}$ & $9.56 \times 10^{-2}$ \\
$\mathrm{SO}_{2}$ & $1.63 \times 10^{-2}$ & $2.86 \times 10^{-2}$ \\
$\mathrm{H}_{2} \mathrm{~S}$ & $8.14 \times 10^{-4}$ & $1.43 \times 10^{-3}$ \\
$\mathrm{H}_{2}$ & $2.11 \times 10^{-4}$ & $3.72 \times 10^{-4}$ \\
$\mathrm{HF}$ & $2.96 \times 10^{-3}$ & $2.20 \times 10^{-3}$ \\
$\mathrm{HCl}$ & $6.87 \times 10^{-3}$ & $1.43 \times 10^{-2}$ \\
$\mathrm{HBr}$ & $9.99 \times 10^{-6}$ & $7.04 \times 10^{-5}$ \\
\hline
\end{tabular}

bration. See also related comments in Roberts et al. (2014). Compared to von Glasow (2010) we used a higher ratio of volcanic volatiles : ambient air $(95: 5)$, which is very rich in volcanic volatiles but already oxidised.

The model is run in Lagrangian mode, following the evolution of a "puff" of plume downwind of the volcano and explicitly modelling the interaction of the plume with background air (see von Glasow, 2010). The modelled wind speed is $10 \mathrm{~m} \mathrm{~s}^{-1}$, and the plume dispersal is assumed to be Gaussian and follows Kärcher (1999) using the Pasquill-Gifford scheme to calculate the parameters of the Gaussian plume (see e.g. Seinfeld and Pandis, 2006).

The $\mathrm{S}$ and $\mathrm{Br}$ elemental ratios of the volcanic volatiles used in the HSC calculation are taken from the average values measured at the crater rim (Table 4, column "low Br / S") on 26 and 27 June 2012. We also did a second set of model runs initialised with a much higher $\mathrm{Br} / \mathrm{S}$ ratio (Table 4, column "high $\mathrm{Br} / \mathrm{S}$ ") based on unpublished data from Alessandro Aiuppa. Table S1 in the Supplement gives the composition of the volcanic volatiles and the results of the HSC calculations used as input for the 1-D model.

The relative humidity varied significantly during the campaign (see Table 3), which is important as the bromine explosion is efficient in the presence of aqueous aerosol.

Following Seinfeld and Pandis (2006) a crystallisation humidity of $40 \%$ for sulphate-containing particles is assumed in the model, but other studies suggest sulphate-containing particles to be liquid for lower relative humidities (e.g. Martin et al., 2003).

Regardless of the exact composition and crystallisation humidity of the volcanic aerosol present on the days of this study when simultaneous $\mathrm{SO}_{2}$ and $\mathrm{O}_{3}$ measurements were made, we wanted to test the implications of crystallised aerosol in the model. We therefore ran the model at the following three different settings regarding the deliquescence of the aerosol:
1. "moist": relative humidity $\sim 57 \%$ (above the sulphate crystallisation humidity assumed in the model); aerosol aqueous phase chemistry occurs throughout the plume;

2. "dry": relative humidity $\sim 21 \%$ (below the assumed sulphate crystallisation humidity); aerosol aqueous phase chemistry consequently disabled; exception is the first $\sim 1 \mathrm{~min}$, where water from the volcano elevates the humidity within the plume;

3. "noHet": where all heterogeneous chemical reactions were deactivated.

Being remote from major sources of anthropogenic pollution and above the planetary boundary layer, the ambient $\mathrm{NO}_{\mathrm{x}}$ levels at Etna are expected to be negligible compared to the amount of nitrogen oxides $\left(\mathrm{NO}_{\mathrm{x}}\right)$ that thermodynamic models such as HSC predict would be formed in the effective source regions of volcanic vents. However Kaschka (2007) and Martin et al. (2012) discussed the problems associated with this, mainly that the time required to reach equilibrium for $\mathrm{NO}_{\mathrm{x}}$ under the given temperatures in the effective source region is, by far, too long. The generation of $\mathrm{NO}_{\mathrm{x}}$ could significantly perturb bromine chemistry due to the formation of $\mathrm{BrNO}_{2}$ (see e.g. Fig. 2 in von Glasow, 2010). A detailed discussion of volcanic plume $\mathrm{Br}-\mathrm{NO}_{\mathrm{x}}$ chemistry, including a modelling study that includes additional $\mathrm{BrNO}_{2}$ reactions, can be found in Roberts et al. (2014). Use of their scheme would likely result in less bromine being present as $\mathrm{BrNO}_{2}$ and might lead to somewhat different $\mathrm{O}_{3}$ development. For each of the three aerosol settings described above, two model runs were done - one with volcanic $\mathrm{NO}_{\mathrm{x}}$ in the quantities predicted in the thermodynamic model and one with no volcanic $\mathrm{NO}_{\mathrm{x}}$. These six runs were performed for both of the plume initialisations shown in Table 4.

\section{1 "Low Br / S" modelled plume}

Model results are shown for the core of the plume which is most appropriate for the grounded plume measured in our campaign. Comparison of modelled and measured plume $\mathrm{SO}_{2}$ mixing ratios, shown in Figs. 6 and 3, respectively, show the plumes to be of similar intensity. Differences in $\mathrm{SO}_{2}$ mixing ratio between the six model runs are negligible. In order to approximately reproduce the measured $\mathrm{SO}_{2}$ mixing ratios at the crater rim, the "initial dilution" ratio of the HSC output with ambient air (see Materials and Methods in von Glasow, 2010) was set to a factor of $9 \times$.

The 0-60 s section of the following figures are not plotted as the first data output from the model occurs at $60 \mathrm{~s}$ after plume release.

Figure 7 shows the modelled ozone depletion in the six runs. Figure 8 shows this as a ratio to $\mathrm{SO}_{2}$ mixing ratio (c.f. Figs. 4 and 5, respectively).

In comparison to the measured data where bromine chemistry at the craters can only be inferred from $\mathrm{O}_{3}$ and $\mathrm{SO}_{2}$ data, 
Table 5. Spectroscopic measurements of the Mount Etna plume. These data are also plotted on Fig. 11. $R^{2}$ refers to the correlation of BrO and $\mathrm{SO}_{2}$ within the measurements.

\begin{tabular}{rccrrr}
\hline Date & $\mathrm{BrO} / \mathrm{SO}_{2}$ & $R^{2}$ & $\begin{array}{r}\text { Distance } \\
(\mathrm{km})\end{array}$ & $\begin{array}{r}\text { Wind speed } \\
\left(\mathrm{m} \mathrm{s}^{-1}\right)\end{array}$ & $\begin{array}{r}\text { Plume age } \\
(\mathrm{min})\end{array}$ \\
\hline $2012-07-24$ & $0.9 \times 10^{-4}$ & 0.94 & 11 & 8.7 & 21 \\
$2012-07-24$ & $0.7 \times 10^{-4}$ & 0.80 & 6.3 & 8.7 & 12 \\
$2012-07-25$ & $1.2 \times 10^{-4}$ & 0.66 & 10.4 & 6.2 & 28 \\
$2012-07-25$ & $1.3 \times 10^{-4}$ & 0.52 & 6.8 & 6.2 & 18 \\
$2012-07-26$ & $1.1 \times 10^{-4}$ & 0.64 & 17 & 9.3 & 30 \\
$2012-07-26$ & $1.0 \times 10^{-4}$ & 0.90 & 8.8 & 9.3 & 16 \\
$2012-07-27$ & $1.2 \times 10^{-4}$ & 0.48 & 16 & 22 & 12 \\
$2012-07-28$ & $0.8 \times 10^{-4}$ & 0.47 & 12 & 13 & 15 \\
$2012-07-28$ & $0.9 \times 10^{-4}$ & 0.50 & 9.0 & 13 & 11 \\
$2012-07-31$ & $0.6 \times 10^{-4}$ & 0.72 & 5.9 & 5.7 & 17 \\
$2012-08-02$ & $1.0 \times 10^{-4}$ & 0.48 & 6.0 & 12 & 8.1 \\
\hline
\end{tabular}

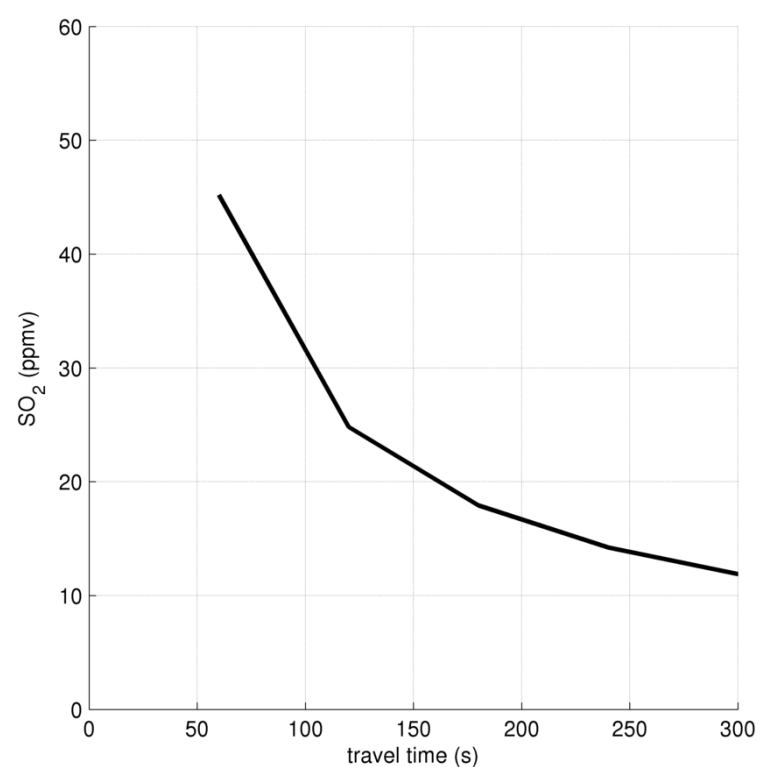

Figure 6. Modelled $\mathrm{SO}_{2}$ mixing ratio in the plume core ("low $\mathrm{Br} / \mathrm{S}$ " initialisation).

the modelled bromine chemistry can be investigated directly; Fig. 9 shows the speciation of bromine in the six different runs.

In all three runs with volcanic $\mathrm{NO}_{\mathrm{x}}$, the bromine almost entirely partitions to $\mathrm{BrNO}_{2} \cdot \mathrm{BrNO}_{2}$ does not contribute to $\mathrm{O}_{3}$ depletion. As shown in Fig. 7 , in these runs the net $\mathrm{O}_{3}$ change is almost zero for all runs and is actually positive in the "noHet" and "dry" cases as a consequence of $\mathrm{O}_{3}$ generating $\mathrm{NO}_{\mathrm{x}}$ chemistry.

The bromine explosion, as evidenced by conversion of $\mathrm{HBr}$ to other forms of bromine can be seen in the "moist" runs and has also occurred between 0 and $60 \mathrm{~s}$ of the "dry" run (where volcanic $\mathrm{H}_{2} \mathrm{O}$ is modelled to increase the plume's

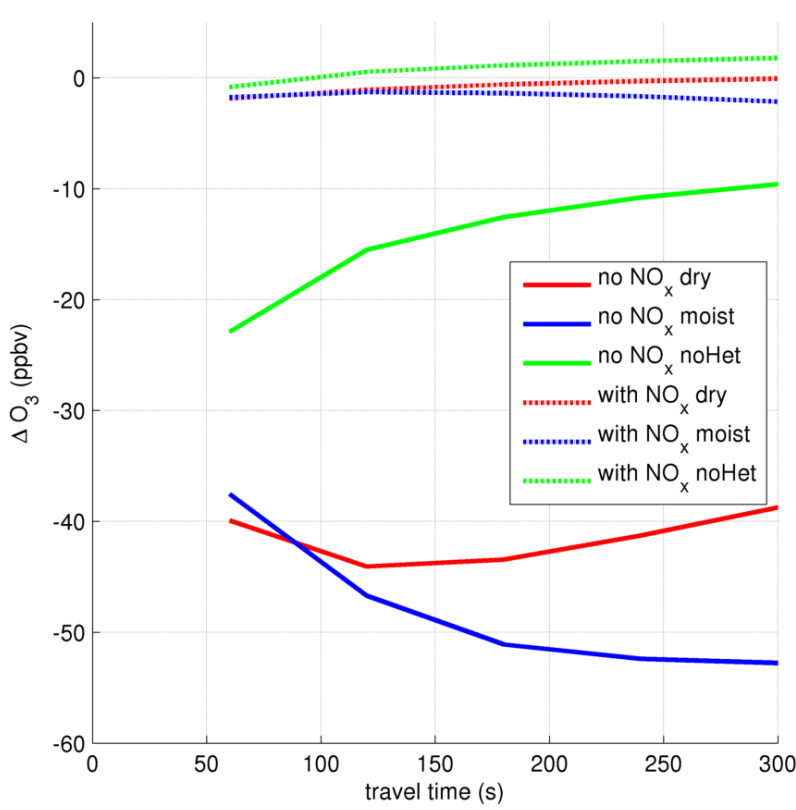

Figure 7. Evolution of $\Delta \mathrm{O}_{3}$ in the core of the plume for the six model scenarios discussed in the text ("low $\mathrm{Br} / \mathrm{S}$ " initialisation).

humidity). In the "noHet" runs and in the "dry" runs after the volcanic humidity increase has ended, the processes that convert $\mathrm{HBr}$ to other forms are effectively halted.

In all three $\mathrm{NO}_{\mathrm{x}}$-free runs, $\mathrm{O}_{3}$ is depleted. Reactive bromine is generated by the high-temperature processes of the effective source region in all three runs. In the "moist" case, and to a slightly reduced extent in the "dry" case, this is supplemented by the generation of reactive bromine species via the bromine explosion, to the extent that in the "moist" case the $\mathrm{O}_{3}$ depletion is near $100 \%$. The consequences of these three runs' differences in bromine chemistry can be 


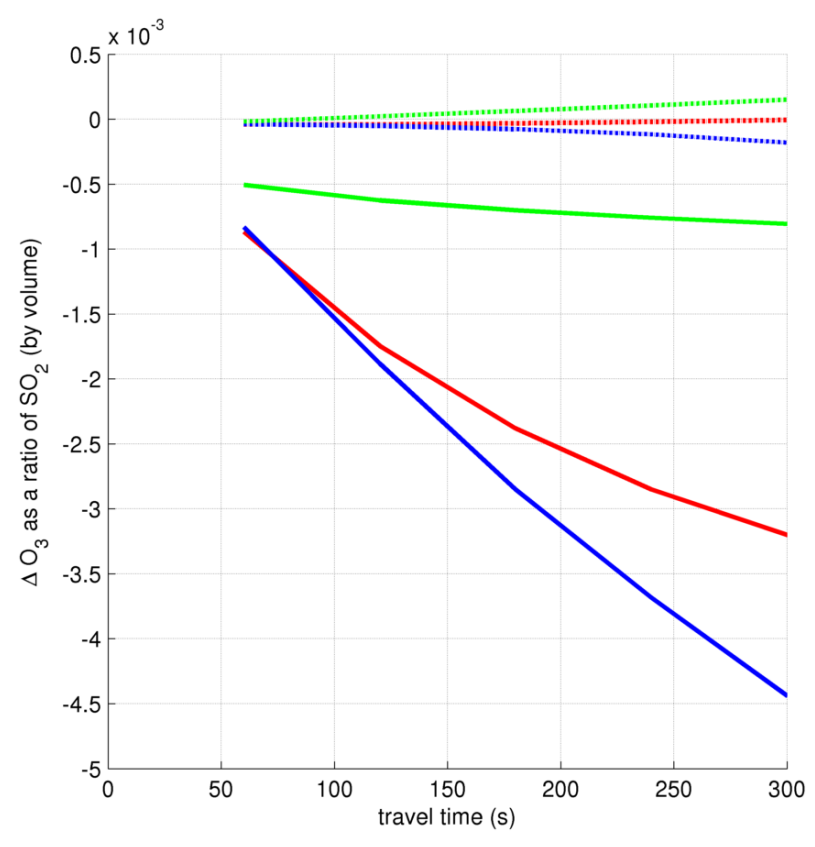

Figure 8. Evolution of $\Delta \mathrm{O}_{3} / \mathrm{SO}_{2}$ in the core of the plume for the six model scenarios discussed in the text ("low $\mathrm{Br} / \mathrm{S}$ " initialisation). The colour code is the same as in Fig. 7.

seen on Fig. 8, where the $\Delta\left[\mathrm{O}_{3}\right] /\left[\mathrm{SO}_{2}\right]$ ratios diverge over the first few minutes.

A comparison of the $\mathrm{O}_{3}$ depletion (Figs. 7 and 8) after $60 \mathrm{~s}$ for the "noHet" run with that for the "dry" and "moist" runs shows the comparative influence of different processes within the crater. The ozone depletion in the "noHet" case must be due to reactive halogen generated in high temperature processes as heterogeneous reactions are required for low-temperature reactive bromine generation (the bromine explosion). The additional ozone depletion at $60 \mathrm{~s}$ in the "dry" and "moist" cases can therefore be attributed to the bromine released via the bromine explosion within the crater. As the plume moves away from the crater, the heterogeneous bromine explosion can only occur in the "moist" run so the increasing differences between the "moist" and "dry" runs are due to the continued bromine explosion in the "moist" run.

The model results can also be used to calculate vertical columns of $\mathrm{BrO}$ and $\mathrm{SO}_{2}$ (Fig. 10) and the corresponding ratios (Fig. 11). These figures show these data over the first 60 min of plume evolution and are also overlayed with the spectroscopic observations listed in Table 5. Due to logistical constraints, we have concurrent near-crater and downwind data only for $27 \mathrm{July}$; this datapoint is highlighted on Fig. 11. As can also be seen in Fig. 9, only the "moist" runs maintain significant amounts of volcanic bromine as $\mathrm{BrO}$ and show column $\mathrm{BrO} / \mathrm{SO}_{2}$ ratios comparable with measurements. Also notable is the rise in the column ratio in the "moist-withNO $\mathrm{x}_{\mathrm{x}}$ " run after a few minutes. After signifi- cant dilution of the plume has occurred, the dominance of the $\mathrm{BrNO}_{2}$ reservoir diminishes. Thus volcanic $\mathrm{NO}_{\mathrm{x}}$, if present, delays but does not prevent in-plume reactive bromine chemistry.

\section{2 "High Br / S" modelled plume}

The elemental emissions ratio of Etna is known to vary between craters and over time (Aiuppa et al., 2005a). Figure 12 shows the evolution of modelled $\Delta \mathrm{O}_{3}$ for the six runs where they have been initialised using the "high $\mathrm{Br} / \mathrm{S}$ " ratios (see Table 4). Further plots relating to these are shown in the supplemental material to this paper (Figs. S1-S5 in the Supplement). As for the runs described previous, in order to approximately reproduce the measured $\mathrm{SO}_{2}$ mixing ratios at the crater rim (and those from the prior runs) an "initial dilution" ratio was again used, in these runs it was set to a factor of $15 \times$ dilution.

The increase in the amount of volcanic bromine has a significant impact on the chemistry. In the $\mathrm{NO}_{\mathrm{x}}$-free runs the reactive bromine generated by the effective source region is sufficient to destroy almost all of the $\mathrm{O}_{3}$ within the plume and the plume chemistry is $\mathrm{O}_{3}$-limited. As can be seen in Table 1 of the supplementary material, the $\mathrm{NO}_{\mathrm{x}} / \mathrm{S}$ ratio is very similar for the "low $\mathrm{Br} / \mathrm{S}$ " and "high $\mathrm{Br} / \mathrm{S}$ " cases. As a consequence the $\mathrm{Br} / \mathrm{NO}_{\mathrm{x}}$ is very different, being 0.0875 in the "low $\mathrm{Br} / \mathrm{S}$ " runs and 3.35 in the "high $\mathrm{Br} / \mathrm{S}$ " runs. Whereas in the "low $\mathrm{Br} / \mathrm{S}$ " runs with volcanic $\mathrm{NO}_{\mathrm{x}}$ almost all reactive $\mathrm{Br}$ had partitioned to $\mathrm{BrNO}_{2}$, in the corresponding "high $\mathrm{Br} / \mathrm{S}$ " the partitioning of the reactive bromine to $\mathrm{BrNO}_{2}$ is more moderate and a significant amount of reactive bromine in other forms remains. This results in moderate $\mathrm{O}_{3}$ depletion in the early plume, with similar variation between the humidity cases as discussed above.

\subsection{Comparison with measured data}

This modelling study shows that the plume chemistry is highly sensitive to several factors: the presence of volcanic $\mathrm{NO}_{\mathrm{x}}$, the magnitude and composition of the primary volcanic emissions, and heterogeneous processes which are dependant on aerosol and humidity. Any comparison between the model results and the measurements must be made with caution. The following points should be stressed:

- Volcanic volatile $\mathrm{Br} / \mathrm{S}$ ratios are known to vary considerably both over time and between Etna's different craters (Aiuppa et al., 2005a). The composition of the volcanic volatiles used in the "low $\mathrm{Br} / \mathrm{S}$ " modelling study was based on measurements which were taken a month prior to the $\mathrm{O}_{3}$ and $\mathrm{SO}_{2}$ measurements. It is unknown how the emissions may have changed in the intervening period, and comparing the results with the two different initialisations shows that variations in volatile composition can be very significant. 

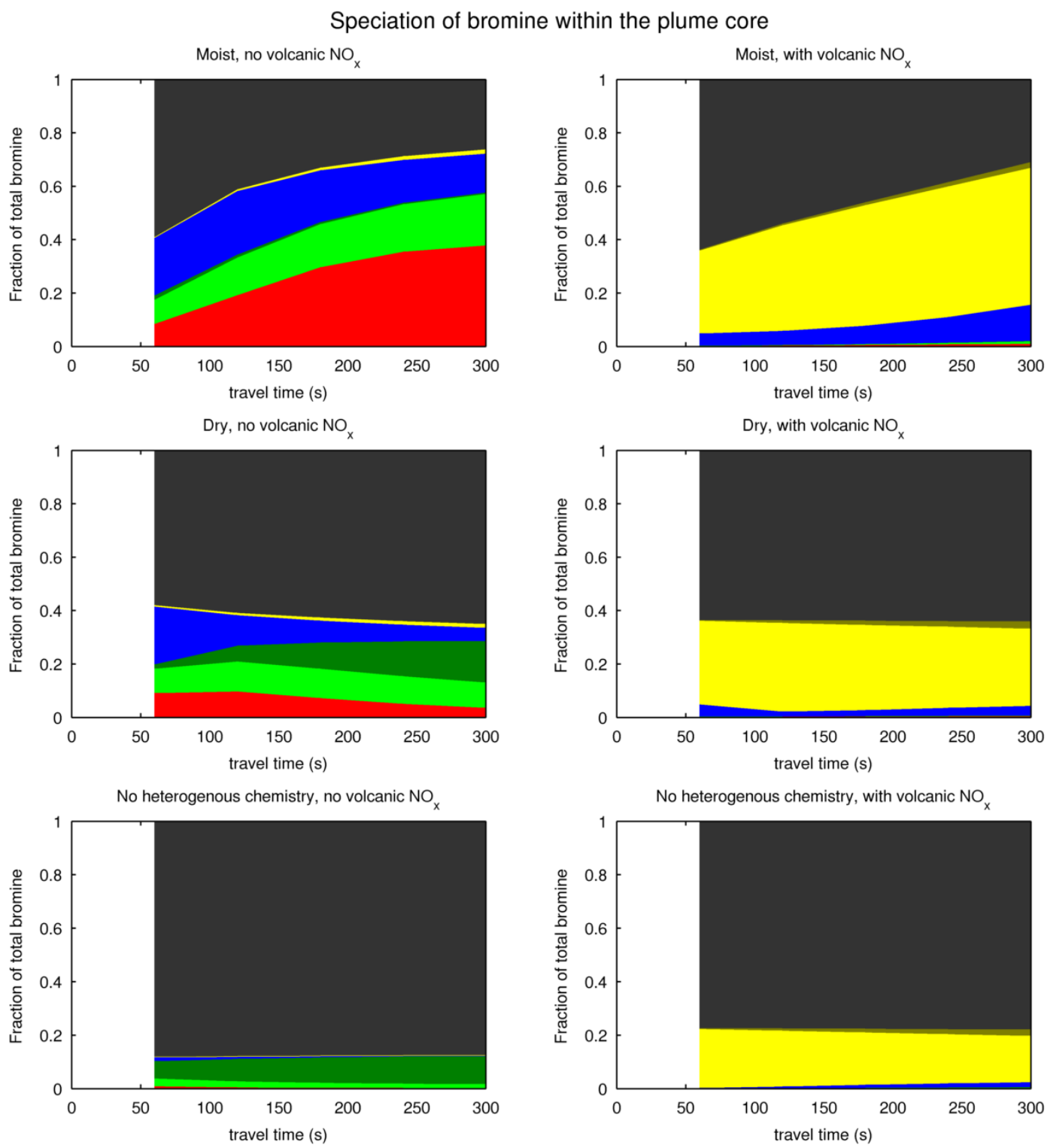

Figure 9. Speciation of bromine for the six model scenarios discussed in the text ("low $\mathrm{Br} / \mathrm{S}$ ” initialisation). $\mathrm{Red}-\mathrm{Br}$; light green - BrO; dark green - $\mathrm{HOBr}$; blue - $\mathrm{Br}$; yellow $-\mathrm{BrNO}_{2}$; grey $-\mathrm{HBr}$.

- Over the time that measurements were taken, the magnitude and composition of the volcanic emissions may have varied significantly. This cannot be reproduced in the model.

- We focussed on model output from the plume core. However, the varying wind velocity at the measurement sites mean that sampling will have been from varying parts of the plume.

As such it is not possible to conclude definitively from the comparison of the measurement and modelling studies the exact chemical processes that were occurring within the plume at the time of the measurement campaign. Nevertheless, the modelling study shows that the reactive bromine generated in the effective-source region is sufficient to cause appreciable ozone depletion within the early plume, however the effect is stronger and more sustained when further reactive bromine can be generated by the bromine explosion.

The model runs which are the best fit for the near-crater $\mathrm{O}_{3}$ and $\mathrm{SO}_{2}$ measurements are not the same runs which best match the $\mathrm{BrO} / \mathrm{SO}_{2}$ columns measured further downwind. This is a discrepancy which highlights the need for further investigation into plume chemistry and the relationship between in-plume bromine, $\mathrm{NO}_{\mathrm{x}}$ and humidity. 


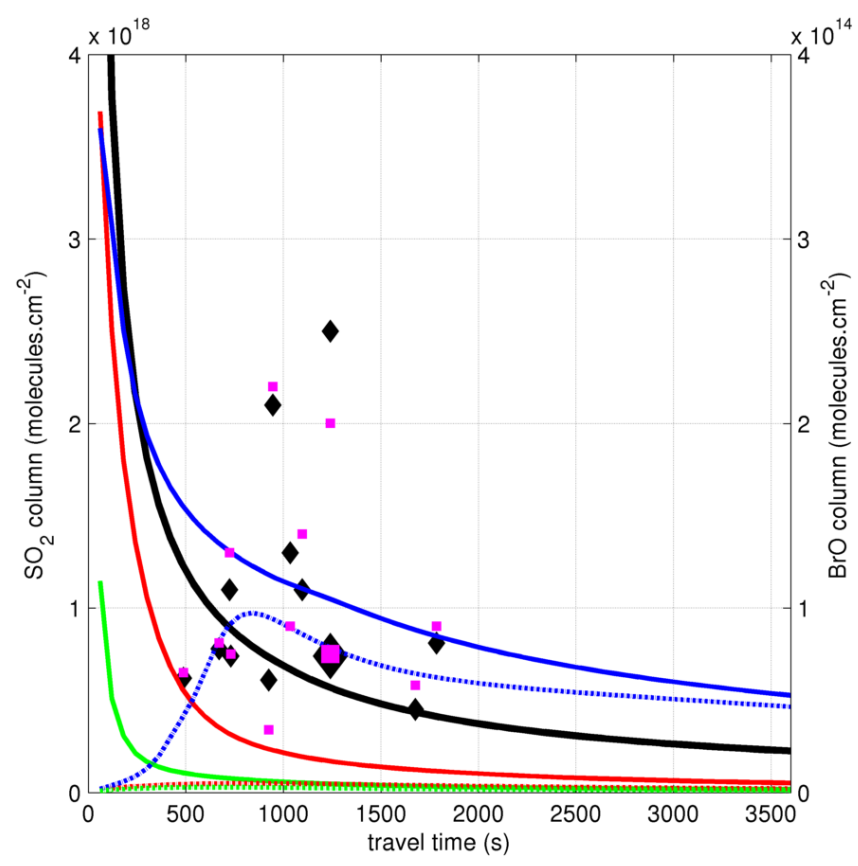

Figure 10. Evolution of vertical column $\mathrm{SO}_{2}$ and $\mathrm{BrO}$ for the six model scenarios discussed in the text ("low $\mathrm{Br} / \mathrm{S}$ " initialisation). $\mathrm{SO}_{2}$ is plotted against the left axis scale in black (variation between the scenarios is minimal). The $\mathrm{BrO}$ columns are plotted against the right axis scale using the same colour code as in Fig. 7. The black diamonds represent the spectroscopic measurements of $\mathrm{SO}_{2}$, the magenta squares represent the spectroscopic measurements of $\mathrm{BrO}$. The larger markers represent the 2012-07-27 measurement contemporaneous with near-crater measurements of both $\mathrm{O}_{3}$ and $\mathrm{SO}_{2}$.

\section{Conclusions}

In this study of chemical evolution in the plumes of Mount Etna during a passively degassing phase we have confirmed $\mathrm{O}_{3}$ depletion to occur less than a few minutes after emission. This extends the limited data set regarding volcanic $\mathrm{O}_{3}$ depletion and is the first data set to date based on groundbased data to include simultaneous measurements of $\mathrm{O}_{3}$ and a plume tracer. The depletion process is ongoing over this time period, and the data suggests it occurred at an approximately constant rate. For the Etna craters measured in late July 2012, this rate was found to be a depletion of approximately $10^{-4}$ molecules of $\mathrm{O}_{3}$ per molecule of $\mathrm{SO}_{2}$ (the inert plume tracer) per second.

Substantial depletion of $\mathrm{O}_{3}$ was observed within minutes after emission, and occurred at very low humidities at which the heterogeneous processes of the bromine explosion would be significantly slowed. On the basis of this, an approximately constant rate of ozone depletion (as a ratio of the inert tracer), and analysis of our modelling study we conclude that most of the very reactive halogens that caused the observed $\mathrm{O}_{3}$ depletion within the 1-4 min old plume were not a product of chemical cycling in the plume once

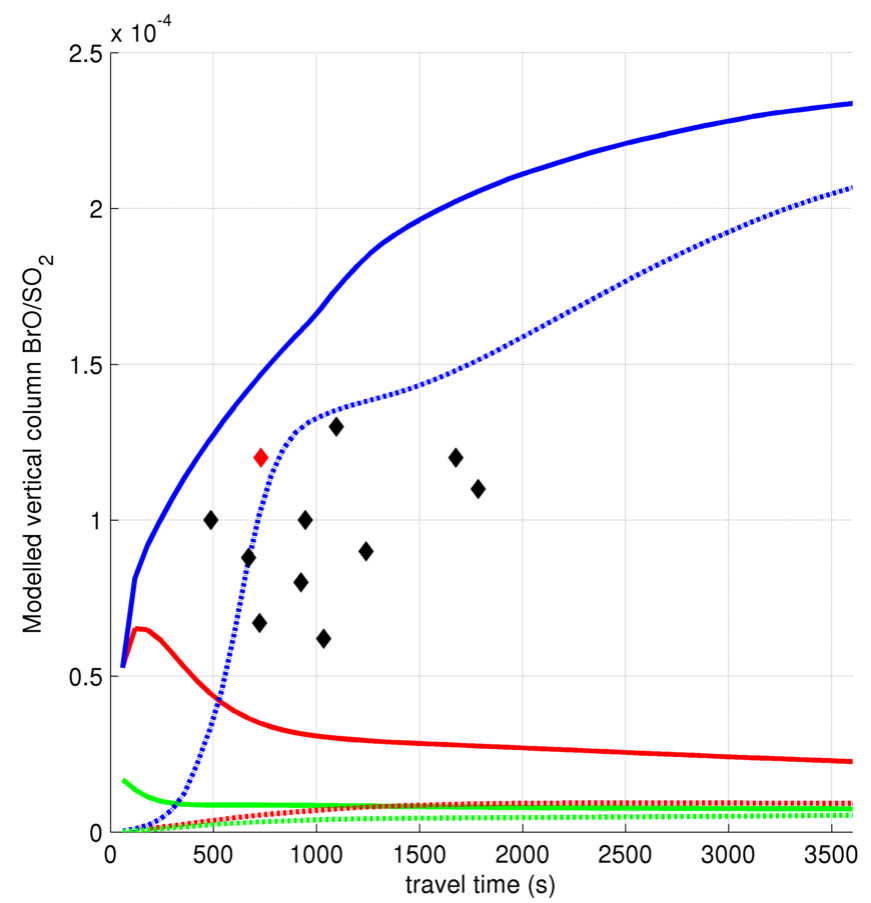

Figure 11. Evolution of vertical column $\mathrm{BrO} / \mathrm{SO}_{2}$ ratios for the six model scenarios discussed in the text ("low $\mathrm{Br} / \mathrm{S}$ " initialisation). The colour code is the same as in Fig. 7. The black diamonds represent the spectroscopic measurements listed in Table 5, the red diamond represents the 2012-07-27 measurement contemporaneous with near-crater measurements of both $\mathrm{O}_{3}$ and $\mathrm{SO}_{2}$.

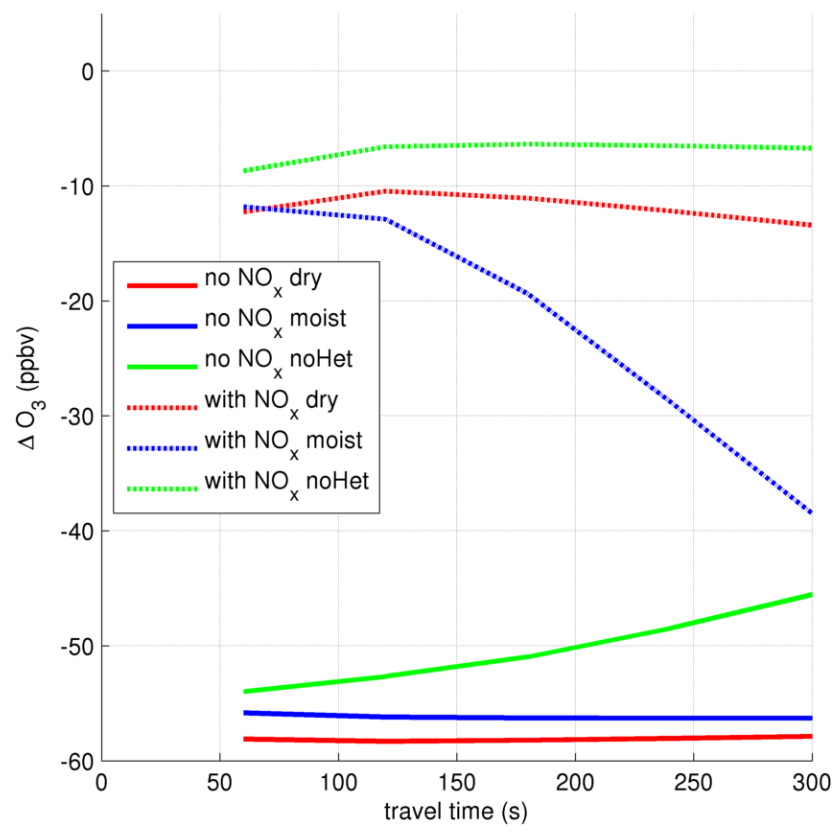

Figure 12. Evolution of $\Delta \mathrm{O}_{3}$ in the core of the plume for the six model scenarios discussed in the text using the "high $\mathrm{Br} / \mathrm{S}$ " initialisation. The colour code is the same as in Fig. 7. 
it had emerged from the crater but rather generated in effective source regions near the vents in high-temperature processes that ceased shortly after emission, and/or very fast low-temperature chemical processes within the crater. This is in agreement with the thermodynamic modelling studies of Gerlach (2004), Martin et al. (2009), and von Glasow (2010) which predict oxidised halogens being produced by hightemperature effective source regions in volcanoes. The in situ measurements in this study were taken at distances less than $500 \mathrm{~m}$ from the vents. Measurements of $\mathrm{BrO} / \mathrm{SO}_{2}$ at such distances tend to be low compared to those measured further downwind (Bobrowski et al., 2007; Boichu et al., 2011). That substantial $\mathrm{O}_{3}$ depletion can occur in such regions suggests these low levels of reactive bromine (and possibly chlorine) species that are generated within the crater are sufficient to cause the $\mathrm{O}_{3}$ depletion observed in this study.

We have also shown that further downwind, contemporaneous spectroscopic observation of the plume shows $\mathrm{BrO} / \mathrm{SO}_{2}$ columns are within the typical range that has been observed within volcanic plumes. Our near-crater measurements are therefore likely to be typical for Mount Etna in its passively degassing phase.
Results from our modelling study suggest that a significant factor influencing the bromine-ozone chemistry in the very early plume is the presence or absence of volcanic $\mathrm{NO}_{\mathrm{x}}$ and, if it is present, its source strength relative to that of $\mathrm{Br}$. The modelling study shows that volcanic $\mathrm{NO}_{\mathrm{x}}$ would be expected to significantly retard early $\mathrm{O}_{3}$ depletion and therefore plume $\mathrm{O}_{3}$ and $\mathrm{Br}$ data could be compared to model output to yield information on $\mathrm{NO}_{\mathrm{x}}$ within a plume. The measured data from this campaign are insufficient to definitively ascertain whether or not volcanic $\mathrm{NO}_{\mathrm{x}}$ generation is occurring but it appears unlikely to be the case as near-crater $\mathrm{O}_{3}$ depletion was observed whilst volcanic $\mathrm{NO}_{\mathrm{x}}$ emissions suppressed such $\mathrm{O}_{3}$ depletion in the modelling study. The modelling study also shows how variations in humidity, and the consequent variations in heterogeneous chemistry, may impact the plume chemistry in detectable ways. A comparison of the results from our three different humidity/heterogeneous chemistry cases gives an indication as to the extents that $\mathrm{O}_{3}$ depletion can be ascribed to reactive halogens generated in high-temperature processes within the crater, lowtemperature processes within the crater, and low temperature processes further downwind. 
Appendix A: Proof that $\Delta \mathrm{O}_{3} / \mathrm{SO}_{2}$ is a measure of chemical change only.

The following is a proof that $\Delta \mathrm{A} / \Delta \mathrm{B}$ cannot be changed by physical plume mixing processes, and thus any change observed in the ratio is the result of chemical change only.

Starting with a generic plume dispersal equation for a change in concentration due to mixing (von Glasow et al., 2003),

$$
\begin{aligned}
\left.\frac{\mathrm{d} c}{\mathrm{~d} t}\right|_{\text {mix }} & =-\frac{1}{A_{\mathrm{p}}} \frac{A_{\mathrm{p}}}{\mathrm{d} t}\left(c-c_{\mathrm{bg}}\right) \\
& =-\omega\left(c-c_{\mathrm{bg}}\right),
\end{aligned}
$$

where $A_{\mathrm{p}}$ is the cross-sectional area of the plume, $\omega=\omega(t)$ is the mixing parameter, $c$ and $c_{\text {bg }}$ are the concentration of the species in the plume and the background air, respectively.

Discretising,

$$
\left.\frac{\delta c}{\delta t}\right|_{\text {mix }}=-\omega\left(c-c_{\text {bg }}\right) .
$$

Let $c_{i}$ be the concentration of the species at time $t_{i}$ :

$c_{2}=c_{1}+\frac{\delta c}{\delta t} \delta t=c_{1}-\omega\left(c_{1}-c_{\mathrm{bg}}\right) \delta t$.

We define

$\Delta c_{i}=c_{i}-c_{\mathrm{bg}}$.

Therefore,

$$
\begin{aligned}
\Delta c_{2} & =c_{1}-\omega\left(c_{1}-c_{\mathrm{bg}}\right) \delta t-c_{\mathrm{bg}} \\
& =\Delta c_{1}-\Delta c_{1} \omega \delta t=\Delta c_{1}(1-\omega \delta t) .
\end{aligned}
$$

Taking the ratio of gas A and gas B,

$\frac{\Delta c_{2}^{\mathrm{A}}}{\Delta c_{2}^{\mathrm{B}}}=\frac{\Delta c_{1}^{\mathrm{A}}(1-\omega \delta t)}{\Delta c_{1}^{\mathrm{B}}(1-\omega \delta t)}=\frac{\Delta c_{1}^{\mathrm{A}}}{\Delta c_{1}^{\mathrm{B}}}$.

In the volcanic case as in this study, $\mathrm{A}=\mathrm{O}_{3}$ and $\mathrm{B}=\mathrm{SO}_{2}$. The concentration of $\mathrm{SO}_{2}$ outside of the plume is negligible in comparison to in-plume measurements, $\mathrm{SO}_{2 \mathrm{bg}} \approx 0$ thus $\Delta \mathrm{SO}_{2}=\mathrm{SO}_{2}$ and $\Delta \mathrm{O}_{3} / \Delta \mathrm{SO}_{2}=\Delta \mathrm{O}_{3} / \mathrm{SO}_{2}$. Therefore,

$$
\frac{\Delta \mathrm{O}_{3,1}}{\mathrm{SO}_{2,1}}=\frac{\Delta \mathrm{O}_{3,2}}{\mathrm{SO}_{2,2}}
$$

Therefore, if no chemical change in $\mathrm{O}_{3}$ occurs between time 1 and time 2 , the ratio remains unchanged. 


\section{The Supplement related to this article is available online at doi:10.5194/acp-15-2613-2015-supplement.}

Acknowledgements. The authors would like to thank Istituto Nazionale di Geofisica e Vulcanologia (INGV) Palermo and Giancarlo Tamburello of the University of Palermo for field support on the July/August 2012 campaign and David Walter, MPI (Max Planck Institute) Mainz, Germany for help in June 2012. We would also like to thank colleagues at the University of East Anglia, in particular Ricky Herd, for their comments on the development of this paper. The campaign was funded by NERC project NE/G015600/1 and Luke Surl's PhD studentship is NERC-funded. Nicole Bobrowski was supported financially by DFG project DFG BO3611/1-1. Allesandro Aiuppa acknowledges funding from the European Research Council under the European Union's Seventh Framework Programme (FP7/2007/2013)/ERC grant agreement $\mathrm{n} 1305377$.

Edited by: R. Sander

\section{References}

Aiuppa, A., Federico, C., Franco, A., Giudice, G., Gurrieri, S., Inguaggiato, S., Liuzzo, M., McGonigle, A. J. S., and Valenza, M.: Emission of bromine and iodine from Mount Etna volcano, Geochem. Geophy. Geosy., 6, Q08008, doi:10.1029/2005gc000965, 2005a.

Aiuppa, A., Inguaggiato, S., McGonigle, A., O’Dwyer, M., Oppenheimer, C., Padgett, M., Rouwet, D., and Valenza, M.: $\mathrm{H}_{2} \mathrm{~S}$ fluxes from Mt. Etna, Stromboli, and Vulcano (Italy) and implications for the sulfur budget at volcanoes, Geochim. Cosmochim. Ac., 69, 1861-1871, doi:10.1016/j.gca.2004.09.018, 2005b.

Aiuppa, A., Franco, A., von Glasow, R., Allen, A. G., D’Alessandro, W., Mather, T. A., Pyle, D. M., and Valenza, M.: The tropospheric processing of acidic gases and hydrogen sulphide in volcanic gas plumes as inferred from field and model investigations, Atmos. Chem. Phys., 7, 1441-1450, doi:10.5194/acp-7-1441-2007, 2007.

Aiuppa, A., Shinohara, H., Tamburello, G., Giudice, G., Liuzzo, M., and Moretti, R.: Hydrogen in the gas plume of an open-vent volcano, Mount Etna, Italy, J. Geophys. Res.-Sol. Ea., 116, B10204, doi:10.1029/2011jb008461, 2011.

Aiuppa, A., Giudice, G., Liuzzo, M., Tamburello, G., Allard, P., Calabrese, S., Chaplygin, I., McGonigle, A. J. S., and Taran, Y.: First volatile inventory for Gorely volcano, Kamchatka, Geophys. Res. Lett., 39, L06307, doi:10.1029/2012g1051177, 2012.

Bagnato, E., Aiuppa, A., Parello, F., Calabrese, S., D’Alessandro, W., T.A., M., McGonigle, A., Pyle, D., and Wängberg, I.: Degassing of gaseous (elemental and reactive) and particulate mercury from Mount Etna volcano (Southern Italy), Atmos. Environ., 41, 7377-7388, doi:10.1016/j.atmosenv.2007.05.060, 2007.

Bobrowski, N. and Giuffrida, G.: Bromine monoxide / sulphur dioxide ratios in relation to volcanological observations at Mt. Etna 2006-2009, Solid Earth, 3, 433-445, doi:10.5194/se-3-4332012, 2012.
Bobrowski, N. and Platt, U.: $\mathrm{SO}_{2} / \mathrm{BrO}$ ratios studied in five volcanic plumes, J. Volcanol. Geoth. Res., 166, 147-160, doi:10.1016/j.jvolgeores.2007.07.003, 2007.

Bobrowski, N., Hönninger, G., Galle, B., and Platt, U.: Detection of bromine monoxide in a volcanic plume, Nature, 423, 273-276, doi:10.1038/nature01625, 2003.

Bobrowski, N., von Glasow, R., Aiuppa, A., Inguaggiato, S., Louban, I., Ibrahim, O. W., and Platt, U.: Reactive halogen chemistry in volcanic plumes, J. Geophys. Res.-Atmos., 112, D06311, doi:10.1029/2006jd007206, 2007.

Boichu, M., Oppenheimer, C., Roberts, T. J., Tsanev, V., and Kyle, P. R.: On bromine, nitrogen oxides and ozone depletion in the tropospheric plume of Erebus volcano (Antarctica), Atmos. Environ., 45, 3856-3866, doi:10.1016/j.atmosenv.2011.03.027, 2011.

Cantrell, C. A.: Technical Note: Review of methods for linear leastsquares fitting of data and application to atmospheric chemistry problems, Atmos. Chem. Phys., 8, 5477-5487, doi:10.5194/acp8-5477-2008, 2008.

Delmelle, P., Delfosse, T., and Delvaux, B.: Sulfate, chloride and fluoride retention in Andosols exposed to volcanic acid emissions, Environ. Pollut., 126, 445-457, doi:10.1016/s02697491(03)00196-9, 2003.

Donovan, A., Tsanev, V., Oppenheimer, C., and Edmonds, M.: Reactive halogens $(\mathrm{BrO}$ and $\mathrm{OClO})$ detected in the plume of Soufrière Hills Volcano during an eruption hiatus, Geochem. Geophy. Geosy., 15, 3346-3363, doi:10.1002/2014GC005419, 2014.

General, S., Bobrowski, N., Pöhler, D., Weber, K., Fischer, C., and Platt, U.: Airborne I-DOAS measurements at Mt. Etna: BrO and $\mathrm{OClO}$ evolution in the plume, J. Volcanol. Geoth. Res., doi:10.1016/j.jvolgeores.2014.05.012, in press, 2014.

Gerlach, T. M.: Volcanic sources of tropospheric ozonedepleting trace gases, Geochem. Geophy. Geosy., 5, Q09007, doi:10.1029/2004gc000747, 2004.

Hobbs, P. V., Tuell, J. P., Hegg, D. A., Radke, L. F., and Eltgroth, M. W.: Particles and Gases in the Emissions from the 1980-1981 Volcanic-Eruptions of Mt St-Helens, J. Geophys. Res.-Oc. Atm., 87, 1062-1086, doi:10.1029/JC087iC13p11062, 1982.

Hörmann, C., Sihler, H., Bobrowski, N., Beirle, S., Penning de Vries, M., Platt, U., and Wagner, T.: Systematic investigation of bromine monoxide in volcanic plumes from space by using the GOME-2 instrument, Atmos. Chem. Phys., 13, 4749-4781, doi:10.5194/acp-13-4749-2013, 2013.

Kaschka, T.: Chemical modelling of volcanic plumes, Diplomarbeit, Universität Heidelberg, Germany, 2007.

Kelly, P. J., Kern, C., Roberts, T. J., Lopez, T., Werner, C., and Aiuppa, A.: Rapid chemical evolution of tropospheric volcanic emissions from Redoubt Volcano, Alaska, based on observations of ozone and halogen-containing gases, J. Volcanol. Geoth. Res., 259, 317-333, doi:10.1016/j.jvolgeores.2012.04.023, 2013.

Kern, C., Sihler, H., Vogel, L., Rivera, C., Herrera, M., and Platt, U.: Halogen oxide measurements at Masaya Volcano, Nicaragua using active long path differential optical absorption spectroscopy, B. Volcanology, 71, 659-670, doi:10.1007/s00445-008-0252-8, 2009.

Kärcher, B.: Aviation-Produced Aerosols and Contrails, Surv. Geophys., 20, 113-167, doi:10.1023/A:1006600107117, 1999. 
Lee, C., Kim, Y. J., Tanimoto, H., Bobrowski, N., Platt, U., Mori, T., Yamamoto, K., and Hong, C. S.: High $\mathrm{ClO}$ and ozone depletion observed in the plume of Sakurajima volcano, Japan, Geophys. Res. Lett., 32, L21809, doi:10.1029/2005g1023785, 2005.

Martin, R. S., Mather, T. A., and Pyle, D. M.: High-temperature mixtures of magmatic and atmospheric gases, Geochem. Geophys. Geosyst., 7, Q04006, doi:10.1029/2005GC001186, 2006.

Martin, R. S., Roberts, T. J., Mather, T. A., and Pyle, D. M.: The implications of $\mathrm{H}_{2} \mathrm{~S}$ and $\mathrm{H}_{2}$ kinetic stability in high-T mixtures of magmatic and atmospheric gases for the production of oxidized trace species (e.g., BrO and $\mathrm{NO}_{\mathrm{x}}$ ), Chem. Geol., 263, 143-150, doi:10.1016/j.chemgeo.2008.12.028, 2009.

Martin, R. S., Ilyinskaya, E., and Oppenheimer, C.: The enigma of reactive nitrogen in volcanic emissions, Geochim. Cosmochim. Ac., 95, 93-105, doi:10.1016/j.gca.2012.07.027, 2012.

Martin, S. T., Schlenker, J. C., Malinowski, A., Hung, H.M., and Rudich, Y.: Crystallization of atmospheric sulfatenitrate-ammonium particles, Geophys. Res. Lett., 30, 2102, doi:10.1029/2003GL017930, 2003.

McGonigle, A. J. S., Delmelle, P., Oppenheimer, C., Tsanev, V. I., Delfosse, T., Williams-Jones, G., Horton, K., and Mather, T. A.: $\mathrm{SO}_{2}$ depletion in tropospheric volcanic plumes, Geophys. Res. Lett., 31, L13201, doi:10.1029/2004g1019990, 2004.

Neri, M., Casu, F., Acocella, V., Solaro, G., Pepe, S., Barardino, P., Sansosti, E., Caltabiano, T., Lundgren, P., and Lanari, R.: Deformation and eruptions at Mt. Etna (Italy): A lesson from 15 years of observations, Geophys. Res. Lett., 36, L02309, doi:10.1029/2008GL036151, 2009.

Oppenheimer, C., Tsanev, V. I., Braban, C. F., Cox, R. A., Adams, J. W., Aiuppa, A., Bobrowski, N., Delmelle, P., Barclay, J., and McGonigle, A. J. S.: BrO formation in volcanic plumes, Geochim. Cosmochim. Ac., 70, 2935-2941, doi:10.1016/j.gca.2006.04.001, 2006.

Oppenheimer, C., Kyle, P., Eisele, F., Crawford, J., Huey, G., Tanner, D., Kim, S., Mauldin, L., Blake, D., Beyersdorf, A., Buhr, M., and Davis, D.: Atmospheric chemistry of an Antarctic volcanic plume, J. Geophys. Res.-Atmos., 115, D04303, doi:10.1029/2009jd011910, 2010.

Pyle, D. M. and Mather, T. A.: Halogens in igneous processes and their fluxes to the atmosphere and oceans from volcanic activity: A review, Chem. Geol., 263, 110-121, doi:10.1016/j.chemgeo.2008.11.013, 2009.

Roberts, T. J., Braban, C. F., Martin, R. S., Oppenheimer, C., Adams, J. W., Cox, R. A., Jones, R. L., and Griffiths, P. T.: Modelling reactive halogen formation and ozone depletion in volcanic plumes, Chem. Geol., 263, 151-163, doi:10.1016/j.chemgeo.2008.11.012, 2009.

Roberts, T. J., Martin, R. S., and Jourdain, L.: Reactive bromine chemistry in Mount Etna's volcanic plume: the influence of total $\mathrm{Br}$, high-temperature processing, aerosol loading and plume-air mixing, Atmos. Chem. Phys., 14, 11201-11219, doi:10.5194/acp-14-11201-2014, 2014.

Roine, A.: HSC chemistry 6.1., Outotec, available at: http://www. outotec.com/en/Products--services/HSC-Chemistry/, 2007.

Saiz-Lopez, A. and von Glasow, R.: Reactive halogen chemistry in the troposphere, Chem. Soc. Rev., 41, 6448-6472, doi:10.1039/c2cs35208g, 2012.

Schumann, U., Weinzierl, B., Reitebuch, O., Schlager, H., Minikin, A., Forster, C., Baumann, R., Sailer, T., Graf, K., Mannstein, H.,
Voigt, C., Rahm, S., Simmet, R., Scheibe, M., Lichtenstern, M., Stock, P., Rüba, H., Schäuble, D., Tafferner, A., Rautenhaus, M., Gerz, T., Ziereis, H., Krautstrunk, M., Mallaun, C., Gayet, J.F., Lieke, K., Kandler, K., Ebert, M., Weinbruch, S., Stohl, A., Gasteiger, J., Groß, S., Freudenthaler, V., Wiegner, M., Ansmann, A., Tesche, M., Olafsson, H., and Sturm, K.: Airborne observations of the Eyjafjalla volcano ash cloud over Europe during air space closure in April and May 2010, Atmos. Chem. Phys., 11, 2245-2279, doi:10.5194/acp-11-2245-2011, 2011.

Seinfeld, J. H. and Pandis, S. N.: Atmospheric Chemistry and Physics, John Wiley \& Sons, New York, Chichester, Weinheim, 2006.

Stutz, J. and Platt, U.: Numerical analysis and estimation of the statistical error of differential optical absorption spectroscopy measurements with least-squares methods, Appl. Optics, 35, 60416053, doi:10.1364/ao.35.006041, 1996.

Symonds, R. B., Rose, W. I., Bluth, G. J. S., and Gerlach, T. M.: Volcanic gas studies - methods, results, and applications, vol. 30 of Reviews in Mineralogy, 1-66, Mineralogical Society of America, USA, 1994.

Theys, N., De Smedt, I., Van Roozendael, M., Froidevaux, L., Clarisse, L., and Hendrick, F.: First satellite detection of volcanic OClO after the eruption of Puyehue-Cordón Caulle, Geophys. Res. Lett., 41, 667-672, doi:10.1002/2013GL058416, 2014.

US EPA: Laboratory study to explore potential interferences to air quality monitors, Research Triangle Park, N.C. : The United States Environmental Protection Agency, Office of Air Quality Planning and Standards, Research Triangle Park, NC 27711, EPA-454/C-00-002, 1999.

van Roozendael, M. and Fayt, C.: WinDOAS 2.1 Software User Manual, BIRA-IASB, available at: http://bro.aeronomie.be/ WinDOAS-SUM-210b.pdf, 2001.

Vance, A., McGonigle, A. J. S., Aiuppa, A., Stith, J. L., Turnbull, K., and von Glasow, R.: Ozone depletion in tropospheric volcanic plumes, Geophys. Res. Lett., 37, L22802, doi:10.1029/2010GL044997, 2010.

von Glasow, R.: Atmospheric chemistry in volcanic plumes, P. Natl. Acad. Sci. USA, 107, 6594-6599, doi:10.1073/pnas.0913164107, 2010.

von Glasow, R., Lawrence, M. G., Sander, R., and Crutzen, P. J.: Modeling the chemical effects of ship exhaust in the cloudfree marine boundary layer, Atmos. Chem. Phys., 3, 233-250, doi:10.5194/acp-3-233-2003, 2003.

von Glasow, R., Bobrowski, N., and Kern, C.: The effects of volcanic eruptions on atmospheric chemistry, Chem. Geol., 263, 131-142, doi:10.1016/j.chemgeo.2008.08.020, 2009.

Wennberg, P.: Atmospheric chemistry - Bromine explosion, Nature, 397, 299-301, doi:10.1038/16805, 1999.

Wesely, M.: Parameterization of surface resistances to gaseous dry deposition in regional-scale numerical models, Atmos. Environ., 23, 1293-1304, doi:10.1016/0004-6981(89)90153-4, 1989.

Wittmer, J., Bobrowski, N., Liotta, M., Giuffrida, G., Calabrese, S., and U., P.: Active alkaline traps to determine acidic-gas ratios in volcanic plumes: sampling technique and analytical Methods, Geochem. Geophys. Geosyst., 15, 2797-2820, doi:10.1002/2013GC005133, 2014. 